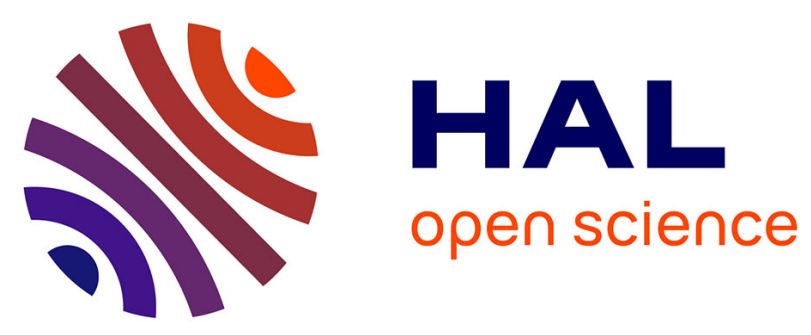

\title{
On pyridopyrazinol chemistry, synthesis of chemiluminescent substances
}

Glwadys Gagnot, Pierre Legrand, Amira Tadros, Fatima Ezzahra Hibti, Alessia Quatela, Yves Louis Janin

\section{- To cite this version:}

Glwadys Gagnot, Pierre Legrand, Amira Tadros, Fatima Ezzahra Hibti, Alessia Quatela, et al.. On pyridopyrazinol chemistry, synthesis of chemiluminescent substances. Synthesis: Journal of Synthetic Organic Chemistry, 2021, 53, 10.1055/a-1396-8607 . pasteur-03175527

\section{HAL Id: pasteur-03175527}

\section{https://hal-pasteur.archives-ouvertes.fr/pasteur-03175527}

Submitted on 20 Mar 2021

HAL is a multi-disciplinary open access archive for the deposit and dissemination of scientific research documents, whether they are published or not. The documents may come from teaching and research institutions in France or abroad, or from public or private research centers.
L'archive ouverte pluridisciplinaire HAL, est destinée au dépôt et à la diffusion de documents scientifiques de niveau recherche, publiés ou non, émanant des établissements d'enseignement et de recherche français ou étrangers, des laboratoires publics ou privés.

\section{(ㅇ)(1) $\$$}

Distributed under a Creative Commons Attribution - NonCommercial| 4.0 International 


\section{On pyridopyrazinol chemistry, synthesis of chemiluminescent substances}

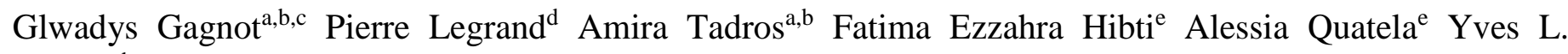
Janin*a,b

a Unité de Chimie et Biocatalyse, Département de Biologie Structurale et Chimie, Institut Pasteur, 28 rue du Dr Roux, 75724 Paris Cedex 15, France

b Unité Mixte de Recherche 3523, Centre National de la Recherche Scientifique, 28 rue du Dr Roux, 75724 Paris Cedex 15, France

yves.janin@cnrs.fr

c Université de Paris, 12 rue de l'école de Médecine, 75006 Paris, France

d Synchrotron Soleil, L'Orme des Merisiers, Saint-Aubin, Gif-sur-Yvette, France

e HORIBA FRANCE SAS, 14 Boulevard Thomas Gobert, Passage Jobin Yvon CS45002, 91120 Palaiseau, France

Our work on new chemiluminescent substances related to the marine luciferin coelenterazine $(\lambda \max =465$ $\mathrm{nm}$ ) led us to attempt the synthesis of four nitrogen-rich pyridopyrazine-bearing analogues. Accordingly, we studied the preparation of the corresponding benzyl-bearing pyridopyrazinols. By varying the conditions of condensations of phenylpyruvic acid and 1,2-diaminopyrine or 3,4-diaminopyridine, all the possible pyridopyrazin-2-ol regioisomers were isolated and properly characterized including by means of crystallographic studies. The ensuing synthesis of the halogenated pyridopyrazines was fraught with difficulties ranging from extensive decomposition to an unexpected ring contraction. In one instance, the inherently reductive mixture of phosphorus oxychloride and phosphorus trichloride provided the 2-benzyl-3chloropyrido[2,3-b]pyrazine. This precursor was then transformed into the target O-acetylated luciferin $(6,8-$ dibenzylimidazo[1,2-a]pyrido[3,2-e]pyrazin-9-yl acetate). The "benzo" derivative of this analogue (e.g.: 2,12-dibenzylimidazo[1',2':1,6]pyrazino[2,3-c]isoquinolin-3-yl acetate) was also made and the chemiluminescence emission spectra of these compounds were determined in a phosphate buffer $(\lambda \max =$ 546 and $462 \mathrm{~nm})$.

Key words chemiluminescence, coelenterazine, imidazo[1,2-a]pyrazin-3(7H)-one, pyridopyrazine, luciferin, heterocycles, rearrangement.

We recently reported on the preparation and chemiluminescence properties of an array of heterocyclic analogues of the luciferin coelenterazine (1) such as compounds $\mathbf{2 a - b}$ depicted in figure 1. ${ }^{1}$ Because of their imidazolone component, such heterocyclic systems will, upon an oxidative decarboxylation process, lead to the production of a photon. ${ }^{1}$ Similarly, reports have described the synthesis and chemi- or bio- luminescence properties of altered luciferins such as the heteroatom-bearing analogues 4-6. In these cases, the structural alterations provided a degree of electron enrichment of the imidazo[1,2-a]pyrazine nucleus and, contrary to the blue-hued derivative $3(\lambda \max =462 \mathrm{~nm})$, their chemiluminescence emission spectra was shifted toward redder wavelengths. ${ }^{2}$ On the other hand, with other type of analogues, we recently achieved a rather modest chemiluminescence shift with a $\lambda \max$ of $513 \mathrm{~nm}$ but only in the case of compound $\mathbf{2} \mathbf{b}$ which is featuring two 
electron-attracting fluorine atoms. ${ }^{1}$ This result drove us to envisage the synthesis of the four possible aza analogues 7-10 in an attempt to study the effect of an additional nitrogen on their chemiluminescence in comparison with compounds 2a-b. In case of a tangible red shift of their chemiluminescence spectra, this would pave the way for a research program aiming at an extensive alteration of the catalytic sites of coelenterazine-using luciferases so that these compounds would become actual substrates and thus provide a red-shifted bioluminescent reporting system. Such approach has actually been successful in the case of a firefly-based luciferin/luciferase bioluminescence system. ${ }^{3}$ Accordingly, we focused on the preparation of the four halogenated pyridopyrazines 11-14 which, as we have demonstrated in other instances, are good intermediates to construct the imidazole component of imidazo[1,2-a]pyrazin-3(7H)-ones as well as many related heterocyclic systems. ${ }^{1,}{ }^{4}$ Synthetic accesses to the chloropyridopyrazines $\mathbf{1 1}$ and $\mathbf{1 2}$ depicted were sought via a chlorination of the corresponding isomeric 2-benzylpyrido[3,4-b]pyrazin-3-ol (17) and 3benzylpyrido[3,4-b]pyrazin-2-ol (20).

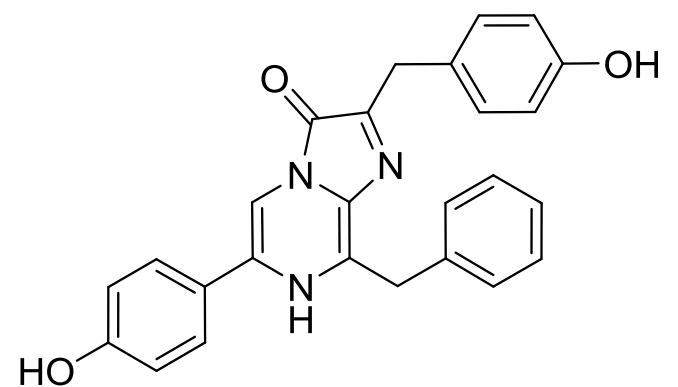

coelenterazine (1)<smiles>[X]c1ccccc1</smiles>

3: $\mathrm{X}=\mathrm{CH}$

4: $X=O$

5: $X=S$

6: $X=S e$<smiles>[X][Y]1cc2nc(Cl)c(Cc3ccccc3)nc2c1</smiles>

11: $\mathrm{X}=\mathrm{N}, \mathrm{Y}=\mathrm{CH}$

12: $X=\mathrm{CH}, Y=N$<smiles>[R]c1cc2[nH]c(Cc3ccccc3)c3nc(Cc4ccccc4)c(=O)n-3c2cc1[R]</smiles>

2a: $\mathrm{R}=\mathrm{H}$

2b: $R=F$<smiles></smiles>

7: $\mathrm{A}=\mathrm{CH}, \mathrm{B}=\mathrm{N}, \mathrm{C}=\mathrm{D}=\mathrm{CH}$

8: $A=B=C H, C=N, D=C H$

9: $A=N, B=C=D=C H$

10: $A=B=C=C H, D=N$<smiles></smiles>

13: $X=\mathrm{N}, \mathrm{Y}=\mathrm{CH}$

14: $\mathrm{X}=\mathrm{CH}, \mathrm{Y}=\mathrm{N}$

Figure 1 Structures of the target compounds 1-10 and intermediates 11-14.

As depicted in scheme 1, to prepare these substances, we started from two reports describing regioselective condensations between 3,4-diaminopyrazine (15) and pyruvic acid or ethyl pyruvate in which the acidity of the reaction medium is actually governing the hydration state of the pyruvate and thus the orientation of the reaction. ${ }^{5}$ Accordingly, we tried these conditions using phenylpyruvic acid (16) instead of pyruvic acid. 
When heating compounds 15 and 16 in ethanol, the reaction led to the isolation of $34 \%$ of the pyrido[3,4b]pyrazin-2-ol 17 which structure was firmly established by means of X-ray based diffraction, as depicted here with the corresponding ORTEP representation. Moreover, sizable amount of the highly insoluble aminoacid 18 was also obtained although this compound could only be partially characterized (by ${ }^{1} \mathrm{H}$ NMR and HRMS) as it turned out to decompose in the course of recrystallization attempts. A drastically different result was obtained when heating compounds 15 and 16 in ethanol along with 3 equivalent of hydrochloric acid $2 \mathrm{~N}$. Indeed, the thick precipitated turned out to be the hydrochloride salt of the imidazopyridine 19a (featuring a $\mathrm{CH}$ signal at $6.74 \mathrm{ppm}$ ) which was isolated in an $83 \%$ yield and fully characterized.

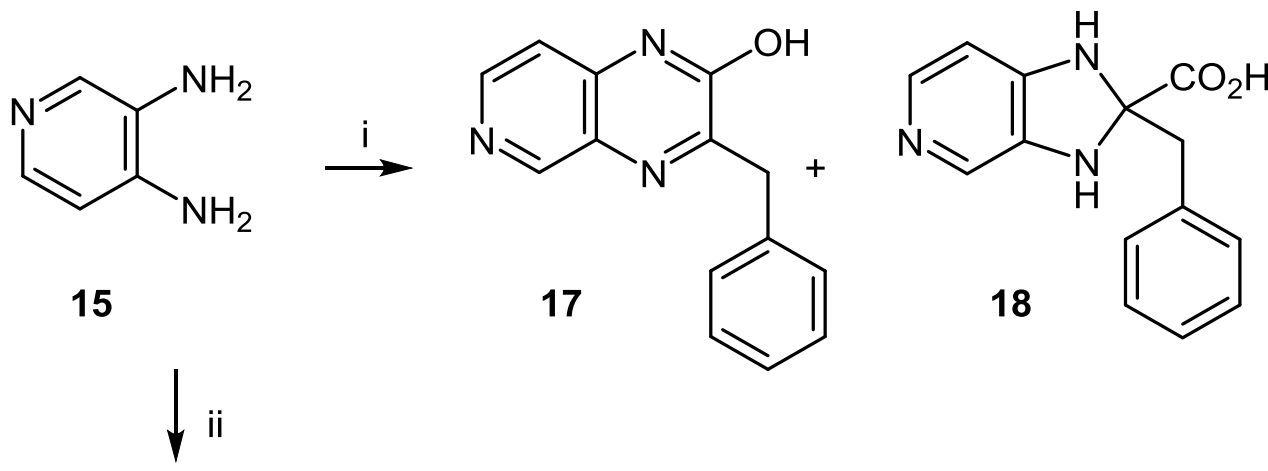

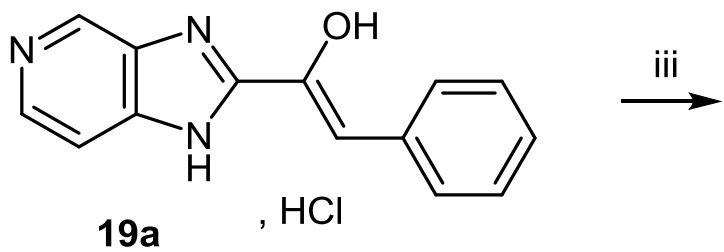

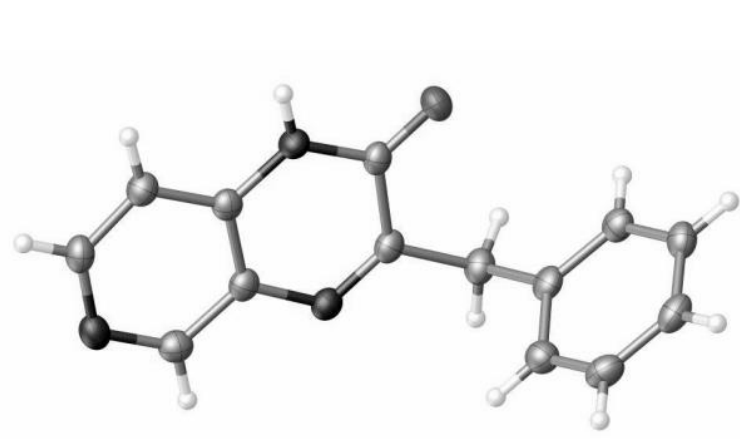

ORTEP of 17<smiles>Oc1nc2cnccc2nc1Cc1ccccc1</smiles>

20<smiles>O=S(=O)(O[Na])O[Na]</smiles><smiles>O/C(=C\c1ccccc1)c1nc2cnccc2[nH]1</smiles>

$19 b$

Scheme $1 \mathrm{i}$ : $\mathrm{PhCH}_{2} \mathrm{COCO}_{2} \mathrm{H}$ (16), EtOH, reflux. ii: $\mathrm{PhCH}_{2} \mathrm{COCO}_{2} \mathrm{H}$ (16), EtOH, $\mathrm{HCl} 2 \mathrm{~N}$ (3 eq.). iii: 1) $\mathrm{EtOH}, \mathrm{NaOH}$, reflux, 3 min, 2) $\mathrm{NH}_{4} \mathrm{Cl}$.

Interestingly, upon a basic treatment of this compound, the target isomeric 2-benzylpyrido[3,4-b]pyrazin-3-ol (20) was then isolated in a $66 \%$ yield after a simple extraction.A microanalysis was actually required to confirm this structure since, in solution, the pyridopyrazin-3-ol 20 (characterized by a $\mathrm{CH}_{2}$ signal at $4.18 \mathrm{ppm}$ and a broad singlet at $12.59 \mathrm{ppm}$ ) slowly isomerized into the free base form of imidazopyridine 19b (displaying a $\mathrm{CH}$ signal at $6.45 \mathrm{ppm}$ as well as two broad singlets at 11.05 and $9.50 \mathrm{ppm}$ ) and appeared to reach a stable 1/1.6 ratio after 48 hours. To conclude this series of unexpected results, all our attempts to obtain the corresponding chloropyridopyrazines 11 or 12, from 17 or 20, using a variety of methods 
unfortunately failed as extensive decompositions were the sole results. Similarly, methylation trials under basic conditions, or using methylorthocarboxylates, ${ }^{6}$ led to complex mixtures of compounds.

As depicted in scheme 2, our attempts to prepare the chloropyridopyrazines 13-14 were somewhat more successful. Again, a regioselective synthesis of the corresponding 2-benzylpyrido[2,3-b]pyrazin-3-ol (22) and 3-benzylpyrido[2,3-b]pyrazin-2-ol (23) relied on the reported mechanistic investigations explaining the orientation of the condensations between 2,3-diaminopyrazine (21) and ethyl pyruvate. ${ }^{5}$ Of note is that if these reports described rather optimists yields and selectivity, a subsequent publication using these reagents reported far more sober results. ${ }^{7}$ In our case, from 2,3-diaminopyrazine (21) and phenylpyruvic acid (16), we obtained mixtures of the target isomers 22 and $\mathbf{2 3}$ in proportion dependent on the reaction conditions. Heating the diamine 21 phenylpyruvic acid (16) in ethanol at $85{ }^{\circ} \mathrm{C}$ in a closed reactor for 26 hours (conditions i) gave the pyridopyrazine isomers 22 and $\mathbf{2 3}$ in respectively 40 and 15\% isolated yield. As depicted with its ORTEP, an X-ray based diffraction analysis again firmly established the structure of compound 22. Moreover, the more polar imidazopyridine derivative $\mathbf{2 4}$ was also detected in the crude reaction products. Under acidic conditions (conditions ii) the proportion of isomer was inversed and compound $\mathbf{2 2}$ and $\mathbf{2 3}$ were isolated in respectively 4 and 33\% yield. Moreover, we could also isolate in this trial $7 \%$ of the rather insoluble imidazopyridine derivative 24. Interestingly, upon treatment of compound $\mathbf{2 4}$ with sodium hydroxide, and contrary to its isomers $\mathbf{1 9}$, this imidazopyridine mostly led to an extensive decomposition. Chlorination of the hydroxypyridopyrazine isomer $\mathbf{2 2}$ was initially problematic, although upon LC/MS monitoring we observed the occurrence of side compounds plausibly arising from oxidation processes. Accordingly, we undertook this reaction in a closed vessel in the presence of phosphorus trichloride as a reducing agent very much compatible with the phosphorus oxychloride used for this reaction. This combination proved to be rewarding and we could isolate compound $\mathbf{1 3}$ in a 55\% yield. On the other hand, the use of these conditions, or many others, to obtain the corresponding chlorinated derivative 14 from compound 23 all failed. In every cases, the imidazopyridine 24 resulting from a remarkable rearrangement was the sole product detected in 1H NMR analysis of the reaction (more is suggested regarding this observation in the conclusion). Nevertheless, from the halogenated pyridopyrazine $\mathbf{1 3}$ we undertook the preparation of the O-acetylated derivative 27, the stabilized precursor of the target compound 9. This proceeded via a Buchwald-Hartwig $\mathrm{N}$-arylation of phenylalanine ethyl ester (25) to give compound $\mathbf{2 6}$ in a rather modest $12 \%$ yield. Then, a saponification followed in situ by the addition of an excess of acetic anhydride gave the $\mathrm{O}$-acetylated derivative $\mathbf{2 7}$ in a $33 \%$ yield after a chromatography. 
<smiles>Nc1cccnc1N</smiles>

21<smiles>O=C(O)C(=O)Cc1ccccc1</smiles>

16<smiles></smiles><smiles>CC#CC(Cc1ccccc1)Cc1nc2cccnc2nc1Cl</smiles>

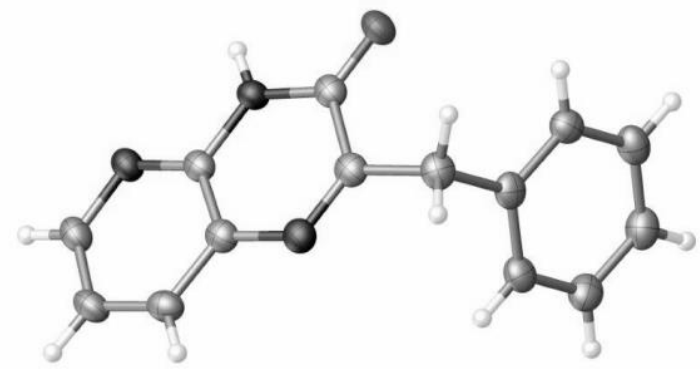

ORTEP of 22<smiles>CCOC(=O)C(Cc1ccccc1)Nc1nc2ncccc2nc1Cc1ccccc1</smiles><smiles>CC(=O)Oc1c(Cc2ccccc2)nc2c(Cc3ccccc3)nc3cccnc3n12</smiles>

$27(33 \%)$

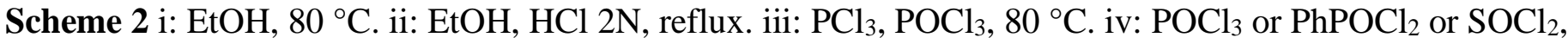
see text. v: $\mathrm{PhCH}_{2} \mathrm{CHNH}_{2} \mathrm{CO}_{2} \mathrm{Et}\left(\right.$ 25), $\mathrm{Pd}(\mathrm{OAc})_{2}, \mathrm{BINAP}, \mathrm{Cs}_{2} \mathrm{CO}_{3}, \mathrm{MeCN}, 90{ }^{\circ} \mathrm{C}$. vi: 1) $\mathrm{NaOH}, \mathrm{THF}, 20{ }^{\circ} \mathrm{C}$, 2) $\mathrm{Ac}_{2} \mathrm{O}, 20^{\circ} \mathrm{C}$.

As depicted in scheme 3 and to conclude this work, we also undertook the preparation of the benzo derivative 34 structurally related to compound 27. To achieve this, we envisaged a copper chloride-catalyzed condensation between the readily available ${ }^{8}$ 4-bromoisoquinolin-3-amine (28) and phenylalanine (29) to give the 1,4-dihydropyrazinoisoquinoline derivative 31. The first report describing similar transformations mentions the use of $1 \%$ of copper chloride, and in most of the examples, the yields described for the corresponding "dihydro" derivative are quite remarkable. ${ }^{9}$ However, in our specific case we had to resort to the use of $10 \%$ of copper chloride to achieve a degree of transformation along with rather low yields. Moreover, we always observed, by LC/MS and ${ }^{1} \mathrm{H}$ NMR spectra, the occurrence of sizable amount of the 
aromatized derivative $\mathbf{3 2}$ which is in accordance with related results described in a subsequent publication. ${ }^{10}$ Along with these two compounds, we also noticed the occurrence of the aminoisoquinoline $\mathbf{3 0}$ plausibly resulting from high temperature DMSO-based reduction process. ${ }^{11}$ Eventually, we employed a different set of reported conditions ${ }^{12}$ involving copper oxide instead of copper chloride, a rather larger excess of amino acid and the much lower reaction temperature of $90^{\circ} \mathrm{C}$ along with a rather extended 40 hours reaction time. In our case, this led to the expected mixture of the dihydro and the aromatized derivatives $\mathbf{3 1}$ and $\mathbf{3 2}$ along with some unreacted 4-bromoisoquinolin-3-amine (28). As fully detailed below, a procedure was then designed to isolate $\mathbf{3 1}$ and $\mathbf{3 2}$ from the reaction mixture and a treatment of the dihydro derivative $\mathbf{3 1}$ with $\mathrm{N}$ bromosuccinimide in ethanol, followed by a filtration, gave additional amount of the aromatized product $\mathbf{3 2}$. With this two stages procedure an overall yield of $30 \%$ of compound $\mathbf{3 2}$ was thus achieved from compound 28. Chlorination of compound 32, using the same combination of $\mathrm{PCl}_{3}$ and $\mathrm{POCl}_{3}$ mentioned above then gave the halogenated derivative 33 in $61 \%$. The next step turned out to be problematic as the BuchwaldHartwig N-arylation of phenylalanine ethyl ester (25) with compound 33, using our previously reported conditions, ${ }^{4}$ invariably led to an extensive decomposition.
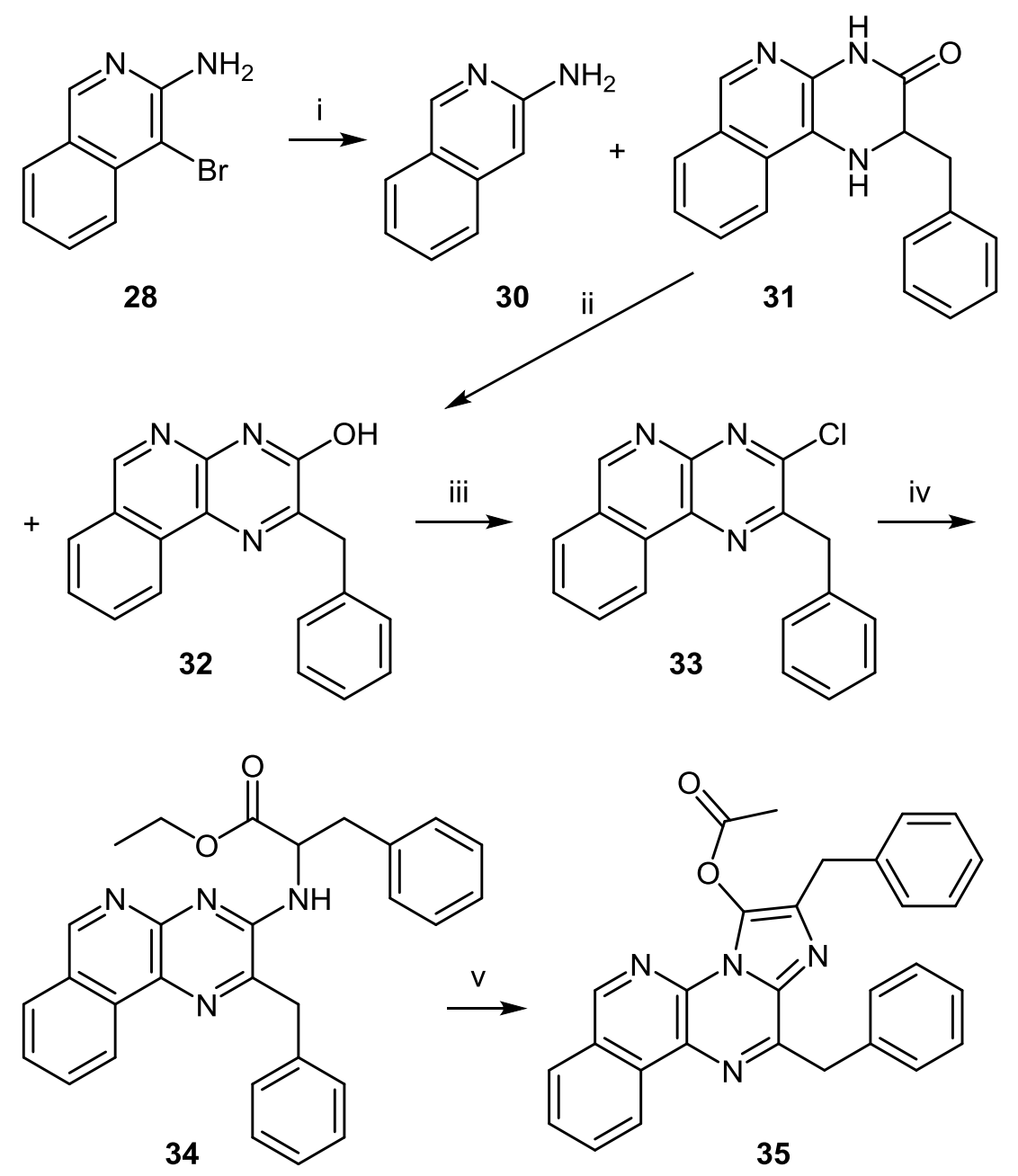

Scheme 3 i: $\mathrm{PhCH}_{2} \mathrm{CHNH}_{2} \mathrm{CO}_{2} \mathrm{H}\left(\right.$ (29), $\mathrm{Cu}_{2} \mathrm{O}, \mathrm{K}_{3} \mathrm{PO}_{4}, \mathrm{DMSO}, 90^{\circ} \mathrm{C}$. ii: NBS, EtOH, $20{ }^{\circ} \mathrm{C}$. iii: $\mathrm{PCl}_{3}, \mathrm{POCl}_{3}$, $80{ }^{\circ} \mathrm{C}$. iv: $\mathrm{PhCH}_{2} \mathrm{CHNH}_{2} \mathrm{CO}_{2} \mathrm{Et}\left(\mathbf{2 5}\right.$, as a free base), NMP, $120{ }^{\circ} \mathrm{C}, 4$ days. v: 1) $\left.\mathrm{NaOH}, \mathrm{THF}, 20{ }^{\circ} \mathrm{C}, 2\right)$ $\mathrm{Ac}_{2} \mathrm{O}, 20^{\circ} \mathrm{C}$.

It is only by heating for four days at $120^{\circ} \mathrm{C}$ a solution of the phenylalanine ethyl ester (25) (as a free base) and 33 in N-methylpyrrolidone (NMP) without any palladium catalyst that a degree of N-arylation was achieved and compound $\mathbf{3 4}$ was isolated in a $10 \%$ yield along with $25 \%$ of the starting material $\mathbf{3 3}$. 
Interestingly, no cyclized product (the target luciferin) could be observed in this step although we previously reported such reaction in another difficult instance under similar reaction conditions. 1 From this ester, a last step gave the target $\mathrm{O}$-acetylated luciferin 35 although in a rather modest $29 \%$ yield as a chromatography turned out to be necessary.

Unexpectedly and probably because of the inherent basicity of their neighboring nitrogen, the acetyl function of compounds 27 and $\mathbf{3 5}$ could not be hydrolyzed under the acidic conditions we previously used ${ }^{4}$ and even trials under harsher (acidic) conditions failed. On the other hand, these acetyls were readily hydrolyzed in a phosphate buffer $(\mathrm{pH}=7.4)$ and, as expected, the resulting luciferin immediately reacted with oxygen to decompose and produce a photon. Accordingly, the determination of the chemiluminescence emission spectra of these two analogues was conducted using their O-acetylated derivatives in this buffer. The use of an Aqualog® (HORIBA Instruments, Inc.), a spectrometer endowed with a sensitive CCD detector (WaterRaman SNR > 20,000:1 - RMS method), was again1 crucial as well as the addition $2.5 \mathrm{mMol}$ of cetyltrimethylammonium bromide to the buffer which led to a great enhancement of their signals. As depicted in the experimental part, the $\lambda$ max measured for the chemiluminescence of compounds 27 and 35 were respectively of 546 and $462 \mathrm{~nm}$ at 2.5 and $5 \mu \mathrm{Mol}$ final concentration.

In conclusion, our attempt to prepare the four possible aza-analogues of luciferin $\mathbf{2 a}$ met quite a lot of unexpected problems. If the preparation and isolation of the benzylpyridopyrazinols 17, 20, 22 and 23 precursors could be achieved in rather modest yields, their transformation into the four corresponding halogenated derivatives turned out to be possible in only one instance. The rather unexpected rearrangement of compound 23 into the imidazopyridine 24 upon treatment with reagents such as $\mathrm{POCl}_{3}$ or $\mathrm{SOCl}_{2}$ is actually providing some insight in the reactivity of such heterocyclic systems and is actually reminiscent of various quinoxalinone ring contractions into benzimidazole previously reported. ${ }^{13}$ In our case, we suggest the mechanism depicted in scheme 4 to account for this experimental fact. The depicted second addition (ii) of phosphorus oxychloride on compound $\mathbf{2 3}$ nitrogen's to give intermediate $\mathbf{3 7}$ could be the key accounting for the fragility of the pyrazine ring and its contraction into the imidazole component of compound $\mathbf{2 4}$ via pentacoordinated phosphor intermediates 38-40. A similar process can also be written with thionylchloride leading then to a tetra-coordinated sulfur intermediate. Of note in this work is the use of the inherently reductive mixture of phosphorus oxychloride and phosphorus trichloride to achieve de preparation of compound $\mathbf{1 3}$ and 33. We are not aware of any reports describing the advantages of using such reaction conditions. Concerning the chemiluminescence study, even if the two O-acetylated proluciferins analogues made 27 and 35 could not be hydrolyzed under acidic conditions, we could determine their emission spectra by adding them to a neutral phosphate buffer which led in situ to the hydrolysis of their acetyl moiety. Interestingly, from compound 27 the luciferin 9 turned out be endowed with yellow colored chemiluminescence spectra ( $\lambda$ max of $546 \mathrm{~nm}$ ), even better than the green-emitting compound $\mathbf{2 b}(\lambda \max =513 \mathrm{~nm})$. On the other hand, in the same phosphate buffer, the benzo derivative 35 gave a blue signal at $462 \mathrm{~nm}$, thus negating any gain from the insertion of the nitrogen in this heterocyclic system. In conclusion, the shift observed from the O-acetylated analogue $\mathbf{2 7}$ is encouraging although the chemistry to generate further derivatives will require to address the difficulties described in this report. In any case, the experimental values of these $\lambda$ max should again ${ }^{4}$ be useful for the design and validation of computer-based models ${ }^{14}$ of such light-producing decarboxylation reactions. 


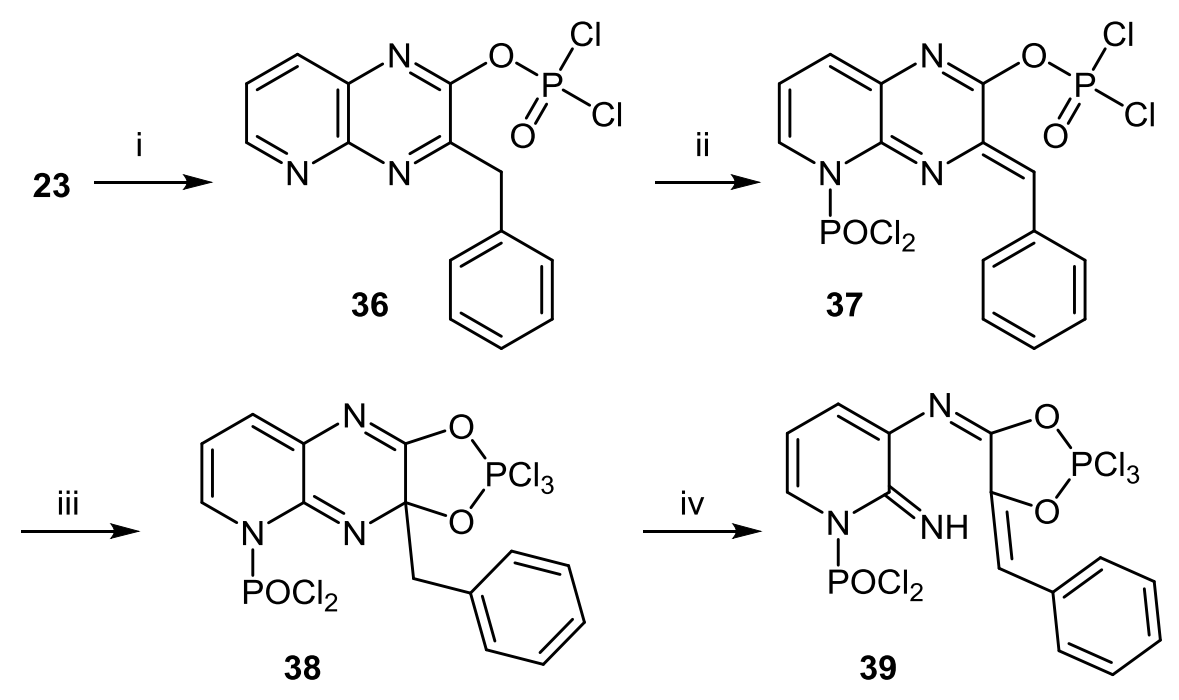

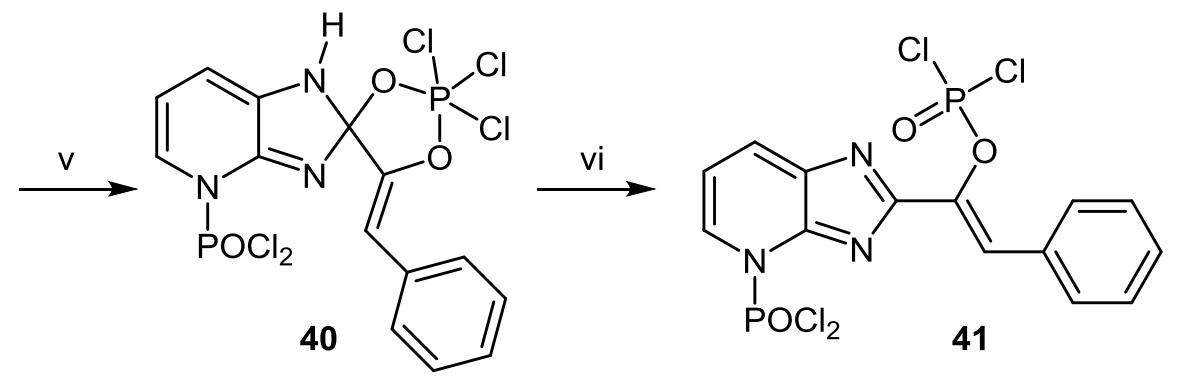<smiles>[Z10]C=Cc1ccccc1/C=C(\O)c1nc2cccnc2[nH]1</smiles>

Scheme 4 Suggested mechanism for the rearrangement of 23 into 24. i: 1st addition of $\mathrm{POCl}_{3},(-\mathrm{HCl})$. ii: $2 \mathrm{nd}$ addition of $\mathrm{POCl}_{3},(-\mathrm{HCl})$. iii: cyclisation $(+\mathrm{HCl})$. iv and $\mathrm{v}$ : rearrangement of the carbon-nitrogen bond. vi: $\mathrm{HCl}$ elimination. vii: hydrolysis (upon treatment) of the two phosphoryl dichlorides. 


\section{Experimental}

X-ray based structure determination. The structural elucidation of compounds $\mathbf{1 7}$ and $\mathbf{2 2}$ was achieved using the beamline PROXIMA-2 at Synchrotron SOLEIL and the data were deposited at the Cambridge Crystallographic Data Centre (CCDC), deposition number 2056217 and 2056386 respectively.

Chemistry. 1H NMR and 13C NMR spectra were recorded on a Bruker Avance 400 spectrometer at 400 $\mathrm{MHz}$ and $100 \mathrm{MHz}$, respectively. Shifts $(\delta)$ are given in ppm with respect to the TMS signal and crosscoupling constants $(\mathrm{J})$ are given in Hertz. Column chromatography were performed either on Merck silica gel $60(0.035-0.070 \mathrm{~mm})$ or neutral alumina containing $1.5 \%$ of added water using a solvent pump and an automated collecting system driven by a UV detector set to $254 \mathrm{~nm}$ unless required otherwise. Sample deposition was carried out by absorption of the mixture to be purified on a small amount of the solid phase followed by its deposition of the top of the column. The low-resolution mass spectra were obtained on an Agilent 1100 series LC/MSD system using an atmospheric electrospray ionization system or an Agilent 1200 series LC/MSD system using an Agilent Jet-Stream atmospheric electrospray ionization system and the highresolution mass spectra (HRMS) were obtained using a Waters Micromass Q-Tof with an electrospray ion source. When specified, the anhydrous solvents used were purchased. Experiments under inert atmosphere were carried out by purging the glassware with a stream of dry argon. Then, an argon balloon, fitted with a needle, was used to insure a positive pressure of inert gas during the reaction. Unless stated otherwise, a purity of at least $95 \%$ was obtained for all the compounds by means of chromatography or recrystallization and this level of purity was established by TLC, LC/MS and NMR spectroscopy.

Chemiluminescence spectra determination. The time-dependent chemiluminescence signal was recorded using an Aqualog (HORIBA Instruments, Inc.) equipped with thermoelectrically cooled charge-coupled device (CCD) array detector. The system uses a xenon-arc light source to excite samples and two detectors for simultaneous Absorbance, Transmission and emission analysis was adapted to the chemiluminescence analysis by blocking the excitation source. The 2D emission spectra were recorded from 250 to $800 \mathrm{~nm}$ using $5 \mathrm{~nm}$ step, high gain and $30 \mathrm{~s}$ integration time for emission detection. A detector accumulation of 2 has been chosen to improve the Signal-to-noise Ratio and increase the photons counts. Chemiluminescence data were corrected for the instrumental emission spectral response, detector dark currents and blank sample emission. All samples were analyzed using $1 \mathrm{~cm}$ path length fluorescence quartz cuvettes and the signal was recorded immediately after addition of either 1 or $2 \mu \mathrm{L}$ of a $5 \mathrm{mM}$ stock solution in DMSO of the O-acetylated luciferin on $2 \mathrm{~mL}$ of a phosphate buffer DPBS GIBCO $1 \mathrm{X}$ which also contained $2.5 \mathrm{mM}$ of cetyltrimethylammonium bromide. The chemiluminescence data were analyzed using Aqualog software based on OriginLab® and the signal was smoothed by 4 points fast Fourier transform (FFT).

Condensation of 3,4-diaminopyrazine (15) and phenylpyruvic acid (16) under neutral conditions. In a $60 \mathrm{~mL}$ tube fitted with a Teflon-covered screw cap, 3,4-diaminopyrazine (15) (1.82 g, $16.67 \mathrm{mmol})$ and phenylpyruvic acid (16) $(2.73 \mathrm{~g}, 16.67 \mathrm{mmol})$ were dispersed in ethanol (40 mL, dried over $4 \AA$ molecular sieves). The tube was closed tightly and heated at $85{ }^{\circ} \mathrm{C}$ for 24 hours. The resulting suspension was dispersed in $100 \mathrm{~mL}$ of boiling ethanol $(100 \mathrm{~mL})$ left to cool and filtered and this material was subjected again to this treatment to give, after drying, compound $18(0.98 \mathrm{~g})$ as a white powder which could not be further purified, probably because of the onset of an oxidative decarboxylation characterized by the appearance in LC/MS of a compound with a mass of $\mathrm{m} / \mathrm{z}=210$. Both filtrates were collected, concentrated to dryness and purified by a chromatography over silica gel (dichloromethane - ethanol 97/3 to 94/6) to yield compound 17 (1.37 g, 34 $\%)$ as a white powder after dispersion of the corresponding fraction in boiling ethanol (100 $\mathrm{mL})$ and filtration after cooling. 


\section{3-Benzylpyrido[3,4-b]pyrazin-2-ol (17)}

Note: the structure of this compound (recrystallized in ethanol) was further established by X-ray crystallography. ${ }^{1} \mathrm{H}$ NMR (DMSO-d6): 12.61 (s (br), 1H), 8.86 (s (br), 1H), 8.45 (d, 1H, J = 5.5 Hz), 7.35$7.27(\mathrm{~m}, 3 \mathrm{H}), 7.39$ (m, 2H), 7.23-7.18 (m, 2H), 4.14 (s, 2H). ${ }^{13} \mathrm{C}$ NMR (DMSO-d6): 162.8, 155.3, 150.2, 149.0, 137.9, 137.4, 129.7, 128.8, 128.6, 126.9, 39.5. HRMS (m/z): $[\mathrm{M}+\mathrm{H}]+$ calcd for $\mathrm{C}_{14} \mathrm{H}_{12} \mathrm{~N}_{3} \mathrm{O}: 238.0980$; found: 238.0975 .

\section{2-Benzyl-2,3-dihydro-1H-imidazo[4,5-c]pyridine-2-carboxylic acid (18)}

${ }^{1} \mathrm{H}$ NMR (DMSO-d6, still containing some EtOH) 9.20 (s (br), 1H), $7.48(\mathrm{~d}, 1 \mathrm{H}, \mathrm{J}=6.1 \mathrm{~Hz}), 7.24(\mathrm{~m}, 2 \mathrm{H})$, 7.18-7.09 (m, 3H), 6.96 (s, 1H), 6.89 (s (br), 1H), 6.17 (d, 1H, J = 6.2 Hz), 3.03 (m, 2H). ${ }^{13} \mathrm{C}$ NMR (DMSOd6): not soluble enough. HRMS (m/z): $[\mathrm{M}+\mathrm{H}]+$ calcd for $\mathrm{C}_{14} \mathrm{H}_{14} \mathrm{~N}_{3} \mathrm{O}_{2}$ : 256.1086; found: 256.1081 .

Note: the growing occurrence of another compound $(\mathrm{m} / \mathrm{z}=210$ and, amongst other, a singlet $1 \mathrm{H}$ signal at $4.23 \mathrm{ppm}$ ) was noticed when trying to further purify this batch using a third dispersion.

Condensation of 3,4-diaminopyrazine (15) and phenylpyruvic acid (16) under acidic conditions, preparation of 1-(1H-imidazo[4,5-c]pyridin-2-yl)-2-phenylethen-1-ol hydrochloride salt (19): A mixture of 3,4-diaminopyrazine (15) (2.26 g, $20.70 \mathrm{mmol})$, phenylpyruvic acid (16) (3.39 g, $20.70 \mathrm{mmol})$, ethanol $(40 \mathrm{~mL})$ and $2 \mathrm{~N}$ hydrochloric acid $(31 \mathrm{~mL}, 62.12 \mathrm{mmol})$ was heated to reflux for 2 hours. This was left to cool, the precipitate was filtered, washed with ethanol and dried under vacuum at $60{ }^{\circ} \mathrm{C}$ to yield pure compound 19 (4.75 g, 83\%) as a hydrochloride salt.

${ }^{1} \mathrm{H}$ NMR (DMSO-d6): 14.40 (s (br), 1H), 11.62 (s, 1H), 10.72 (s (br), 1H), 8.15 (dd, 1H, J = 1.0, 6.6 Hz), $8.03(\mathrm{~d}, 1 \mathrm{H}, \mathrm{J}=1.0 \mathrm{~Hz}), 7.56(\mathrm{~m}, 2 \mathrm{H}), 7.47(\mathrm{~m}, 2 \mathrm{H}), 7.41(\mathrm{~d}, 1 \mathrm{H}, \mathrm{J}=6.6 \mathrm{~Hz}), 7.36(\mathrm{~m}, 1 \mathrm{H}), 6.74(\mathrm{~s}, 1 \mathrm{H}) .{ }^{13} \mathrm{C}$ NMR (DMSO-d6): 157.6, 141.6, 136.1, 133.8, 129.3 (two signals), 128.4, 127.0, 125.0, 124.6, 111.5, 109.1. HRMS (m/z): $[\mathrm{M}+\mathrm{H}]+$ calcd for $\mathrm{C}_{14} \mathrm{H}_{12} \mathrm{~N}_{3} \mathrm{O}: 238.0980$; found: 238.0985 . Anal. calcd. for $\mathrm{C}_{14} \mathrm{H}_{11} \mathrm{~N}_{3} \mathrm{O}+\mathrm{HCl}$ : C, 61.43; H, 4.42; N, 15.35; O, 5.85. Found: C, 61.23; H, 4.42; N, 15.41; O, 6.14.

\section{2-benzylpyrido[3,4-b]pyrazin-3-ol (20)}

Compound $19(0.19 \mathrm{~g}, 0.69 \mathrm{mmol})$ and sodium hydroxide $(0.2 \mathrm{~g}, 5 \mathrm{mmol})$ were brought to reflux in ethanol/water 1-1 (20 mL). This was left to cool, neutralized with solid ammonium chloride diluted in water and extracted with ethyl acetate $(2 \times 50 \mathrm{~mL})$. The organic layer was washed with brine $(25 \mathrm{~mL})$, dried over magnesium sulfate and concentrated to dryness to yield pure compound $\mathbf{2 0}(0.11 \mathrm{~g}, 66 \%)$ as a beige powder. If ${ }^{1} \mathrm{H}$ and ${ }^{13} \mathrm{C} \mathrm{NMR}$ analysis were run using a freshly made sample of compound $\mathbf{2 0}$, the following spectra were obtained:

${ }^{1} \mathrm{H}$ NMR (DMSO-d6): 12.59 (s (br), 1H), 8.63 (d, 1H, J = 0.6 Hz), 8.40 (d, 1H, J = 5.3 Hz), 7.65 (dd, 1H, J = 0.6, $5.3 \mathrm{~Hz}), 7.34-7.27$ (m, 4H), 7.22 (m, 1H), 4.18 (s, 2H). ${ }^{13} \mathrm{C}$ NMR (DMSO-d6): 167.0, 154.6, 143.9, $139.1,137.1,135.7,129.8,128.8,128.5,127.0,121.5,39.7$.

Following about 24 hours in the DMSO-d6 solution, the occurrence of a second product could be seen and subtraction of the signal described above gave the following spectra compatible with the free base form of compound 19:

${ }^{1} \mathrm{H}$ NMR (DMSO-d6): 11.05 (s (br), 1H), 9.50 (s (br), 1H), 7.99 (s, 1H), 7.92 (d, 1H, J = 5.5 Hz), 7.52 (d, 2H, $\mathrm{J}=7.9 \mathrm{~Hz}), 7.41(\mathrm{~m}, 2 \mathrm{H}), 7.26(\mathrm{~m}, 2 \mathrm{H}), 7.06(\mathrm{~d}, 1 \mathrm{H}, \mathrm{J}=5.5 \mathrm{~Hz}), 6.44$ (s, 1H). ${ }^{13} \mathrm{C}$ NMR (DMSO-d6): 158.8, $144.5,135.6,135.2,134.6,129.2,129.0,128.7,127.1,122.8,108.6,105.2$. HRMS (m/z): $[\mathrm{M}+\mathrm{H}]+$ calcd for $\mathrm{C}_{14} \mathrm{H}_{12} \mathrm{~N}_{3} \mathrm{O}$ : 238.0980; found: 238.0983. Note: when using formic acid as vector, a peak at $\mathrm{m} / \mathrm{z}=256.1074$ 
was also present. Anal. calcd. for $\mathrm{C}_{14} \mathrm{H}_{11} \mathrm{~N}_{3} \mathrm{O}$ : C, 70.87; H, 4.67; N, 17.71; O, 6.74. Found: C, 70.39; $\mathrm{H}, 4.81$; $\mathrm{N}, 17.63 ; \mathrm{O}, 6.77$.

Condensation of 2,3-diaminopyrazine (21) and phenylpyruvic acid (16) under neutral conditions. In a $60 \mathrm{~mL}$ tube fitted with a Teflon-covered screw cap, 1,2-diaminobenzene (21) (1.39 g, $12.73 \mathrm{mmol})$ and phenylpyruvic acid (16) $(2.09 \mathrm{~g}, 12.73 \mathrm{mmol})$ were heated at $85{ }^{\circ} \mathrm{C}$ in ethanol $(25 \mathrm{~mL})$ for 26 hours. The resulting solution was concentrated to dryness and the residue purified by a chromatography over silica gel (dichloromethane - ethanol 98/2 to 96/4) to give, in that order of elution, compound $22(1.21 \mathrm{~g}, 40 \%)$ and its isomers $23(0.48 \mathrm{~g}, 15 \%)$ as described below.

Condensation of 2,3-diaminopyrazine (21) and phenylpyruvic acid (16) under acidic conditions. A mixture of 1,2-diaminobenzene (21) (1.32 g, $12.10 \mathrm{mmol})$, phenylpyruvic acid (16) (2.00 g, $12.10 \mathrm{mmol})$, and $2 \mathrm{~N}$ hydrochloric acid $(18.1 \mathrm{~mL}, 36.29 \mathrm{mmol})$ were heated to reflux in ethanol $(20 \mathrm{~mL})$ for 26 hours. The resulting solution was cooled, diluted in water $(100 \mathrm{~mL})$, made basic with solid sodium hydrogenocarbonate. The resulting precipitate was filtered and the filtrate extracted with ethyl acetate $(2 \times 50 \mathrm{~mL})$. The organic layer was washed with water $(30 \mathrm{~mL})$, brine $(30 \mathrm{~mL})$, dried over magnesium sulfate and concentrated to dryness. This residue and the insoluble material described above, were both adsorbed over silica gel and purified by a chromatography over silica gel (dichloromethane - ethanol 98/2) to give an unclean fraction containing compound $22(0.25 \mathrm{~g})$ and then a clean fraction of compound $23(0.95 \mathrm{~g}, 33 \%)$. Further purification of the first fraction by a second chromatography over silica gel (cyclohexane - ethyl acetate 2/1 to $1 / 0)$ gave pure compound $22(0.11 \mathrm{~g}, 4 \%)$. In another trial, extensive dispersion of the initial precipitate in ethyl acetate $(100 \mathrm{~mL})$ and water $(100 \mathrm{~mL})$ followed by a filtration of the remaining insoluble material gave a solid which was purified by a chromatography over silica gel (dichloromethane - ethanol 97/3) to give a fraction $(0.98 \mathrm{~g})$ containing the imidazo[4,5-b]pyridine 24 . This was further purified by a dispersion in boiling ethanol $(40 \mathrm{~mL})$ to give a pure sample of $24(0.32 \mathrm{~g}, 7 \%)$ as described below.

\section{2-benzylpyrido[2,3-b]pyrazin-3-ol (22)}

Note: as described above, the structure of this compound (recrystallized in ethanol) was further established by X-ray crystallography and the $1 \mathrm{H}$ spectra is similar to the substance obtained using a different (but plausibly acid-containing) synthetic approach, endowed with very optimistic yields which we could not reproduce. ${ }^{15}$

${ }^{1} \mathrm{H}$ NMR (DMSO-d6): 12.84 (s (br), 1H), 8.48 (dd, 1H, J = 4.7, $1.7 \mathrm{~Hz}$ ), 8.14 (dd, 1H, J = 7.8, 1.7 Hz), 7.37$7.27(\mathrm{~m}, 5 \mathrm{H}), 7.22(\mathrm{~m}, 1 \mathrm{H}), 4.15$ (s, 2H). ${ }^{13} \mathrm{C}$ NMR (DMSO-d6): 164.1, 156.3, 150.1, 144.3, 137.5, 136.7, 129.7, 128.8, 127.3, 126.9, 102.1, 39.3. HRMS (m/z): $[\mathrm{M}+\mathrm{H}]+$ calcd for $\mathrm{C}_{14} \mathrm{H}_{11} \mathrm{~N}_{3} \mathrm{ONa}$ : 260.0800; found: 260.0805.

\section{3-benzylpyrido[2,3-b]pyrazin-2-ol (23)}

${ }^{1} \mathrm{H}$ NMR (DMSO-d6): 12.51 (s (br), 1H), 8.48 (dd, 1H, J = 4.5, $1.7 \mathrm{~Hz}$ ), 7.69 (dd, 1H, J = 8.2, 1.7 Hz), 7.51 $(\mathrm{dd}, 1 \mathrm{H}, \mathrm{J}=8.1,4.5 \mathrm{~Hz}), 7.37-7.20$ (m, 5H), 4.18 (s, 2H) ${ }^{13} \mathrm{C}$ NMR (DMSO-d6): 164.7, 154.6, 145.3, 143.0, 137.4, 129.8, 128.8, 128.3, 126.9, 125.2, 124.6, 39.6. HRMS (m/z): $[\mathrm{M}+\mathrm{H}]+$ calcd for $\mathrm{C}_{14} \mathrm{H}_{12} \mathrm{~N}_{3} \mathrm{O}: 238.0980$; found: 238.0971 .

\section{1-(1H-Imidazo[4,5-b]pyridin-2-yl)-2-phenylethen-1-ol (24)}

${ }^{1} \mathrm{H}$ NMR (DMSO-d6): 11.06 (s (br), 1H), 9.20 (s (br), 1H), 7.80 (dd, 1H, J = 1.4, 4.9 Hz), 7.55 (m, $2 \mathrm{H}$ ), 7.39 $(\mathrm{m}, 2 \mathrm{H}), 7.24(\mathrm{~m}, 1 \mathrm{H}), 7.16(\mathrm{dd}, 1 \mathrm{H}, \mathrm{J}=1.4,7.7 \mathrm{~Hz}), 6.80(\mathrm{dd}, 1 \mathrm{H}, \mathrm{J}=4.9,7.7 \mathrm{~Hz}), 6.41(\mathrm{~m}, 1 \mathrm{H}) .{ }^{13} \mathrm{C} \mathrm{NMR}$ (DMSO-d6): 158.6, 141.6, 135.4, 129.8, 129.3, 129.2, 128.5, 127.0, 121.5, 121.1, 116.3, 105.1. HRMS $(\mathrm{m} / \mathrm{z}):[\mathrm{M}+\mathrm{H}]+$ calcd for $\mathrm{C}_{14} \mathrm{H}_{12} \mathrm{~N}_{3} \mathrm{O}: 238.0980$; found: 238.0969 . 


\section{2-Benzyl-3-chloropyrido[2,3-b]pyrazine (13)}

In a $60 \mathrm{~mL}$ tube fitted with a Teflon-covered screw cap, compound $23(0.4 \mathrm{~g}, 1.68 \mathrm{mmol})$ was dispersed in a mixture of phosphorus oxychloride $(4 \mathrm{~mL})$ and phosphorus trichloride $(2 \mathrm{~mL})$. The tube was closed and heated at $80{ }^{\circ} \mathrm{C}$ with an oil bath for $40 \mathrm{~min}$. The resulting solution was diluted in ethyl acetate $(100 \mathrm{~mL})$, poured onto an excess of ice and stirred for 15 minutes. The organic layer was made basic with $1 \mathrm{~N}$ ammonia, washed with water $(30 \mathrm{~mL})$, brine $(30 \mathrm{~mL})$, dried over magnesium sulfate and concentrated to dryness. The residue was purified by a chromatography over silica gel (cyclohexane - ethyl acetate 3/1) to give compound $13(0.35 \mathrm{~g}, 81 \%)$ as a white solid.

${ }^{1} \mathrm{H}$ NMR $\left(\mathrm{CDCl}_{3}\right): 9.13(\mathrm{dd}, 1 \mathrm{H}, \mathrm{J}=1.9,4.2 \mathrm{~Hz}), 7.73(\mathrm{dd}, 1 \mathrm{H}, \mathrm{J}=4.2,8.3 \mathrm{~Hz}), 7.73(\mathrm{dd}, 1 \mathrm{H}, \mathrm{J}=1.9,8.3$ $\mathrm{Hz}), 7.34$ (m, 5H), 4.57 (s, 2H). ${ }^{13} \mathrm{C} \mathrm{NMR}\left(\mathrm{CDCl}_{3}\right)$ : 155.9, 154.1, 150.6, 149.4, 137.9, 136.2, 136.1, 129.2, 128.6, 127.0, 125.4, 41.8. HRMS (m/z): $[\mathrm{M}+\mathrm{H}]+$ calcd for $\mathrm{C}_{14} \mathrm{H}_{11} \mathrm{~N}_{3} \mathrm{Cl}$ : 256.0641; found: 256.0634.

\section{Ethyl (2-benzylpyrido[2,3-b]pyrazin-3-yl)phenylalaninate (26)}

In a $20 \mathrm{~mL}$ sealable vial fitted with a septum, compound $13(0.31 \mathrm{~g}, 1.21 \mathrm{mmol})$, phenylalanine ethyl ester hydrochloride salt $(0.28 \mathrm{~g}, 1.21 \mathrm{mmol})$, cesium carbonate $(1.3 \mathrm{~g}, 3.87 \mathrm{mmol})$, palladium diacetate $(0.013 \mathrm{~g}$, $0.06 \mathrm{mmol})$ and BINAP $(0.053 \mathrm{~g}, 0.084 \mathrm{mmol})$ were weighted. The air was replaced by argon and, under an inert atmosphere, dry acetonitrile $(4 \mathrm{~mL})$ was injected. This was stirred and heated at $60{ }^{\circ} \mathrm{C}$ for 12 hours. The resulting suspension was diluted in ethyl acetate $(75 \mathrm{~mL})$, filtered, the filtrate was concentrated to dryness and the residue purified by a chromatography over silica gel (cyclohexane - ethyl acetate 2/1) to give compound $26(0.06 \mathrm{~g}, 12 \%)$ as an oil.

${ }^{1} \mathrm{H}$ NMR $\left(\mathrm{CDCl}_{3}\right): 8.86(\mathrm{dd}, 1 \mathrm{H}, \mathrm{J}=2.0,4.5 \mathrm{~Hz}), 8.25(\mathrm{dd}, 1 \mathrm{H}, \mathrm{J}=2.0,8.1 \mathrm{~Hz}), 7.38(\mathrm{dd}, 1 \mathrm{H}, \mathrm{J}=8.1,4.5$ Hz), $7.29(\mathrm{~m}, 3 \mathrm{H}), 7.18(\mathrm{~m}, 5 \mathrm{H}), 6.89(\mathrm{~m}, 2 \mathrm{H}), 5.64(\mathrm{~d}, 1 \mathrm{H}, \mathrm{J}=7.4 \mathrm{~Hz}), 5.38(\mathrm{~m}, 1 \mathrm{H}), 4.24(\mathrm{~s}, 2 \mathrm{H}), 4.14(\mathrm{~m}$, $2 \mathrm{H}), 3.34(\mathrm{dd}, 1 \mathrm{H}, \mathrm{J}=5.4,14.2 \mathrm{~Hz}), 3.17(\mathrm{dd}, 1 \mathrm{H}, \mathrm{J}=5.2,14.2 \mathrm{~Hz}), 1.22(\mathrm{t}, 3 \mathrm{H}, \mathrm{J}=7.2 \mathrm{~Hz}) .{ }^{13} \mathrm{C} \mathrm{NMR}$ $\left(\mathrm{CDCl}_{3}\right): 171.6,152.0,151.5,151.0,147.7,137.2,135.9,135.0,131.4,129.3,129.1,128.6,127.4,126.8$, 120.4, 61.5, 54.3, 41.3, 37.1, 14.2. HRMS (m/z): $[\mathrm{M}+\mathrm{H}]+$ calcd for $\mathrm{C}_{25} \mathrm{H}_{25} \mathrm{~N}_{4} \mathrm{O}_{2}$ : 413.1978; found: 413.1980 .

\section{6,8-Bibenzylimidazo[1,2-a]pyrido[3,2-e]pyrazin-9-yl acetate (27)}

Compound 26 (0.06 g, $0.14 \mathrm{mmol})$ and powdered sodium hydroxide $(0.023 \mathrm{~g}, 0.58 \mathrm{mmol})$ were weighted in a $100 \mathrm{~mL}$ flask. The air was replaced by argon and dry THF $(0.2 \mathrm{~mL})$ was injected. This was stirred for 19 hours and acetic anhydride $(0.2 \mathrm{~mL}, 2.18 \mathrm{mmol})$ was then injected. The resulting suspension was stirred for 2 hours, diluted in water, stirred for 15 minutes and extracted with ethyl acetate $(2 \times 50 \mathrm{~mL})$. The organic layer was washed with water $(30 \mathrm{~mL})$, brine $(30 \mathrm{~mL})$, dried over magnesium sulfate and concentrated to dryness. The residue was purified by a chromatography over silica gel (cyclohexane - ethyl acetate 4/1) to give compound $27(0.02 \mathrm{~g}, 33 \%)$ as a pale pink glass.

${ }^{1} \mathrm{H}$ NMR $\left(\mathrm{CDCl}_{3}\right): 8.52(\mathrm{dd}, 1 \mathrm{H}, \mathrm{J}=1.7,4.7 \mathrm{~Hz}), 8.31(\mathrm{dd}, 1 \mathrm{H}, \mathrm{J}=1.7,8.2 \mathrm{~Hz}), 7.60(\mathrm{~m}, 2 \mathrm{H}), 7.47(\mathrm{dd}, 1 \mathrm{H}, \mathrm{J}$ $=4.7,8.2 \mathrm{~Hz}), 7.38-7.18(\mathrm{~m}, 8 \mathrm{H}), 4.63(\mathrm{~s}, 2 \mathrm{H}), 4.22(\mathrm{~s}, 2 \mathrm{H}), 2.39(\mathrm{~s}, 3 \mathrm{H}) .{ }^{13} \mathrm{C} \mathrm{NMR}\left(\mathrm{CDCl}_{3}\right): 168.7,155.4$, $146.9,139.5,138.4,137.4,137.3,134.5,134.4,131.9,131.1,129.8,129.0,128.4,128.3,126.6,126.4,122.1$, 39.6, 33.1, 20.4. HRMS (m/z): [M+H]+ calcd for $\mathrm{C}_{25} \mathrm{H}_{21} \mathrm{~N}_{4} \mathrm{O}_{2}$ : 409.1664; found: 409.1667.

\section{4-Bromoisoquinolin-3-amine (28)}

The procedure described on page 67 of a patent ${ }^{8}$ was followed and compound $28(7.09 \mathrm{~g}, 87 \%)$ was obtained as a yellow powder after a purification by chromatography over silica gel (cyclohexane - ethyl acetate 4/1).

${ }^{1} \mathrm{H}$ NMR $\left(\mathrm{CDCl}_{3}\right): 8.81(\mathrm{~s}, 1 \mathrm{H}), 7.93(\mathrm{~m}, 1 \mathrm{H}), 7.81(\mathrm{~m}, 1 \mathrm{H}), 7.67(\mathrm{~m}, 1 \mathrm{H}), 7.34(\mathrm{~m}, 1 \mathrm{H}), 5.03$ (s $\left.(\mathrm{br}), 2 \mathrm{H}\right)$. ${ }^{13} \mathrm{C} \mathrm{NMR}\left(\mathrm{CDCl}_{3}\right): 151.7,150.5,137.0,131.9,128.1,124.8,123.8,123.6,97.6$. 


\section{2-Benzylpyrazino[2,3-c]isoquinolin-3-ol (32)}

In a $60 \mathrm{~mL}$ tube fitted with a Teflon-covered screw cap, compound 28 (1.61 g, $7.21 \mathrm{mmol})$, racemic phenylalanine $(\mathbf{2 9}, 3.6 \mathrm{~g}, 21.6 \mathrm{mmol})$, potassium phosphate $(4.6 \mathrm{~g}, 7.21 \mathrm{mmol})$, copper I oxide $(0.05 \mathrm{~g}, 0.36$ mmol) were weighted. Dry DMSO $(15 \mathrm{~mL})$ was added, the tube closed and heated, using an oil bath, at 90 ${ }^{\circ} \mathrm{C}$ for 40 hours. The resulting orange suspension was dispersed in a mixture of water $(100 \mathrm{~mL})$, ethyl acetate $(50 \mathrm{~mL})$, ammonium chloride $(1.1 \mathrm{~g})$ and $30 \%$ ammonia $(10 \mathrm{~mL})$ and stirred in open air for 30 minutes. The resulting precipitate was filtered, washed with water $(2 \times 50 \mathrm{~mL})$, ethyl acetate $(2 \times 50 \mathrm{~mL})$ and dried under vacuum at $50{ }^{\circ} \mathrm{C}$ to give pure compound $32(0.38 \mathrm{~g}, 18 \%)$ as a white powder. The filtrate was extracted with ethyl acetate $(2 \times 50 \mathrm{~mL})$, the organic layer was washed with water $(30 \mathrm{~mL})$, brine $(30 \mathrm{~mL})$, dried over magnesium sulfate and concentrated to dryness. A chromatography over silica gel (cyclohexane - ethyl acetate 2/1) of the resulting residue gave an impure fraction containing the dihydro derivative $31(0.47 \mathrm{~g})$. This was dispersed in ethanol, N-bromosuccinimide was added $(0.43 \mathrm{~g})$ and the suspension stirred for 90 minutes. The resulting precipitate was filtered, washed with ethanol and dried under vacuum at $50{ }^{\circ} \mathrm{C}$ to give some more compound $32(0.26 \mathrm{~g}, 12 \%)$.

${ }^{1} \mathrm{H}$ NMR (DMSO-d6): 13.1 (s, 1H), 9.29(s, 1H), $8.60(\mathrm{~m}, 1 \mathrm{H}), 8.20(\mathrm{~m}, 1 \mathrm{H}), 7.93(\mathrm{~m}, 1 \mathrm{H}), 7.68(\mathrm{~m}, 1 \mathrm{H})$, $7.41(\mathrm{~m}, 2 \mathrm{H}), 7.32(\mathrm{~m}, 2 \mathrm{H}), 7.23(\mathrm{~m}, 1 \mathrm{H}), 4.25$ (s, 2H). ${ }^{13} \mathrm{C}$ NMR (DMSO-d6): 160.2, 156.5, 154.5, 139.7, $137.8,133.3,132.7,129.8,128.8,128.7,126.9,126.8,126.4,121.4,119.9,39.5 . \mathrm{HRMS}(\mathrm{m} / \mathrm{z}):[\mathrm{M}+\mathrm{H}]+$ calcd for $\mathrm{C}_{18} \mathrm{H}_{14} \mathrm{~N}_{3} \mathrm{O}: 288.1137$; found: 288.1136 .

\section{2-Benzyl-3-chloropyrazino[2,3-c]isoquinoline (33)}

In a $60 \mathrm{~mL}$ tube fitted with a Teflon-covered screw cap, compound 32 (1.4 g, $4.59 \mathrm{mmol})$ was dispersed in a mixture of phosphorus oxychloride $(10 \mathrm{~mL})$ phosphorus trichloride $(5 \mathrm{~mL})$. The tube was closed and heated at $120{ }^{\circ} \mathrm{C}$ with an oil bath for 23 hours. The resulting solution was diluted in ethyl acetate $(100 \mathrm{~mL})$, poured onto an excess of ice and stirred for 15 minutes. The organic layer was made basic with $1 \mathrm{~N}$ ammonia, washed with water $(2 \times 30 \mathrm{~mL})$, brine $(30 \mathrm{~mL})$, dried over magnesium sulfate and concentrated to dryness. The residue was purified by a chromatography over silica gel (cyclohexane - ethyl acetate 4/1) to give compound $33(0.90 \mathrm{~g}, 61 \%)$ as a white solid.

${ }^{1} \mathrm{H} \mathrm{NMR}\left(\mathrm{CDCl}_{3}\right): 9.55(\mathrm{~s}, 1 \mathrm{H}), 9.11(\mathrm{~m}, 1 \mathrm{H}), 8.17(\mathrm{~m}, 1 \mathrm{H}), 8.02(\mathrm{~m}, 1 \mathrm{H}), 7.91(\mathrm{~m}, 1 \mathrm{H}), 7.44(\mathrm{~m}, 2 \mathrm{H}), 7.34$ $(\mathrm{m}, 2 \mathrm{H}), 7.26(\mathrm{~m}, 1 \mathrm{H}), 4.64(\mathrm{~s}, 2 \mathrm{H}) .{ }^{13} \mathrm{C} \mathrm{NMR}\left(\mathrm{CDCl}_{3}\right): 158.0,154.0,148.4,146.5,136.7,133.7,133.2$, 132.2, 129.9, 129.3, 128.6, 128.5, 128.2, 126.9, 123.8, 41.6. HRMS (m/z): $[\mathrm{M}+\mathrm{H}]+$ calcd for $\mathrm{C}_{18} \mathrm{H}_{13} \mathrm{ClN}_{3}$ : 306.0798; found: 306.0793 .

\section{Ethyl (2-benzylpyrazino[2,3-c]isoquinolin-3-yl)phenylalaninate (34)}

In a $60 \mathrm{~mL}$ tube fitted with a Teflon-covered screw cap, compound $33(0.43 \mathrm{~g}, 1.41 \mathrm{mmol})$ and freshly extracted phenylalanine ethyl ester (25) $(0.55 \mathrm{~g}, 2.81 \mathrm{mmol})$ were dissolved in dry N-methylpyrrolidone (4 $\mathrm{mL}$ ). The tube was closed and heated, using an oil bath, at $120{ }^{\circ} \mathrm{C}$ for four days. The resulting black solution was diluted in saturated sodium hydrogenocarbonate $(150 \mathrm{~mL})$, this was extracted with ethyl acetate $(2 \times 50$ $\mathrm{mL})$, the organic layer was washed with water $(30 \mathrm{~mL})$, brine $(30 \mathrm{~mL})$, dried over magnesium sulfate and concentrated to dryness. The residue was purified by a chromatography over silica gel (cyclohexane - ethyl acetate $3 / 1)$ to give compound $34(0.14 \mathrm{~g}, 10 \%)$ as an oil. In another chromatographic fraction pure starting material $33(0.14 \mathrm{~g}, 25 \%)$ was recovered.

${ }^{1} \mathrm{H} \mathrm{NMR}\left(\mathrm{CDCl}_{3}\right): 9.40(\mathrm{~s}, 1 \mathrm{H}), 9.00(\mathrm{~m}, 1 \mathrm{H}), 8.05(\mathrm{~m}, 1 \mathrm{H}), 7.88(\mathrm{~m}, 1 \mathrm{H}), 7.69(\mathrm{~m}, 1 \mathrm{H}), 7.28(\mathrm{~m}, 5 \mathrm{H}), 7.19$ $(\mathrm{m}, 3 \mathrm{H}), 6.94(\mathrm{~m}, 2 \mathrm{H}), 5.46(\mathrm{~m}, 2 \mathrm{H}), 4.33(\mathrm{~s}, 2 \mathrm{H}), 4.17(\mathrm{~m}, 2 \mathrm{H}), 3.38(\mathrm{dd}, 1 \mathrm{H}, \mathrm{J}=4.9,14.0 \mathrm{~Hz}), 3.22(\mathrm{dd}$, $1 \mathrm{H}, \mathrm{J}=5.3,14.0 \mathrm{~Hz}), 1.24(\mathrm{t}, 3 \mathrm{H}, \mathrm{J}=7.3 \mathrm{~Hz}) .{ }^{13} \mathrm{C} \mathrm{NMR}\left(\mathrm{CDCl}_{3}\right): 172.0,155.8,151.2,147.2,144.6,136.2$, 
$135.8,134.3,131.3,129.4,129.0,128.7,128.6,128.4,127.9,127.2,127.0,126.8,126.7,122.3,61.4,54.4$, 41.1, 37.4, 14.1. HRMS (m/z): [M+H]+ calcd for $\mathrm{C}_{29} \mathrm{H}_{27} \mathrm{~N}_{4} \mathrm{O}_{2}$ : 463.2129; found: 463.2124.

\section{2,12-Dibenzylimidazo[1',2':1,6]pyrazino[2,3-c]isoquinolin-3-yl acetate (35)}

Compound $34(0.14 \mathrm{~g}, 0.30 \mathrm{mmol})$ and powdered sodium hydroxide $(0.05 \mathrm{~g}, 1.2 \mathrm{mmol})$ were weighted in a $100 \mathrm{~mL}$ flask. The air was replaced by argon and dry THF $(3 \mathrm{~mL})$ was injected. This was stirred for 19 hours and acetic anhydride $(0.43 \mathrm{~mL}, 4.51 \mathrm{mmol})$ was then injected. The resulting suspension was stirred for 2 hours, diluted in water $(50 \mathrm{~mL})$, stirred for 15 minutes and extracted with ethyl acetate $(2 \times 50 \mathrm{~mL})$. The organic layer was washed with water $(30 \mathrm{~mL})$, brine $(30 \mathrm{~mL})$, dried over magnesium sulfate and concentrated to dryness. The residue was purified by a chromatography over silica gel (cyclohexane - ethyl acetate 6/1) to give compound $\mathbf{3 5}(0.04 \mathrm{~g}, 29 \%)$ as a beige solid.

${ }^{1} \mathrm{H} \mathrm{NMR}\left(\mathrm{CDCl}_{3}\right)$ : $9.07(\mathrm{~s}, 1 \mathrm{H}) 9.4(\mathrm{~m}, 1 \mathrm{H}), 8.0(\mathrm{~m}, 1 \mathrm{H}), 7.87(\mathrm{~m}, 1 \mathrm{H}), 7.67(\mathrm{~m}, 3 \mathrm{H}), 7.41(\mathrm{~m}, 2 \mathrm{H}), 7.35(\mathrm{~m}$, $4 \mathrm{H}), 7.26(\mathrm{~m}, 2 \mathrm{H}), 4.75(\mathrm{~s}, 2 \mathrm{H}), 4.28(\mathrm{~s}, 2 \mathrm{H}), 2.42(\mathrm{~s}, 3 \mathrm{H}) .{ }^{13} \mathrm{C} \mathrm{NMR}\left(\mathrm{CDCl}_{3}\right): 168.9,153.3,150.3,138.5$, 137.7, 134.9, 134.8, 134.1, 134.0, 131.5, 131.4, 129.9, 129.0, 128.4, 128.3, 127.5, 127.4, 126.5, 126.3, 125.4, 123.5, 39.5, 33.4, 20.5 (one signal missing). HRMS (m/z): $[\mathrm{M}+\mathrm{H}]+$ calcd for $\mathrm{C}_{29} \mathrm{H}_{23} \mathrm{~N}_{4} \mathrm{O}_{2}$ : 459.1821; found: 459.1822 .

\section{Acknowledgment and funds}

G.G. acknowledges a PhD fellowship from the Université Paris Descartes, Sorbonne Paris Cité. This project also benefited from the Valoexpress funding calls of the Institut Pasteur.

We thank Dr. Ahmed Haouz of the PF6 core facility of the Institut Pasteur for crystal freezing and data collection. We acknowledge SOLEIL (Saint-Aubin, France) for provision of synchrotron radiation facilities and we would like to thank the staff of PROXIMA-2 for assistance in using beamline. We also thank Dr. Florence Miller from Berthold Technologies for her support.

\section{References}

(1) Gagnot, G.; Hervin, V.; Coutant, E.P.; Goyard, S.; Jacob, Y.; Rose, T.; Hibti, F.E.; Quatela, A.; Janin, Y.L. Chem. Eur. J. 2020, doi.org/10.1002/chem.202004311.

(2) (a) Giuliani, G.; Cappelli, A.; Vomero, S.; Anzini, M. Patent WO 2011007314; (b) Giuliani, G.; Molinari, P.; Ferretti, G.; Cappelli, A.; Anzini, M.; Vomero, S.; Costa, T. Tetrahedron Lett. 2012, 53, 5114; (c) Yuan, M.-L.; Jiang, T.-Y.; Du, L.-P.; Li, M.-Y. Chin. Chem. Lett. 2016, 27, 550; (d) Yeh, H.W.; Karmach, O.; Ji, A.; Carter, D.; Martins-Green, M.M.; Ai, H.W. Nature Methods 2017, 14, 971; (e) Giuliani, G.; Merolla, A.; Paolino, M.; Reale, A.; Saletti, M.; Blancafort, L.; Cappelli, A.; Benfenati, F.; Cesca, F. Photochem. Photobiol. 2020, doi: 10.1111/php.13347.

(3) Yao, Z.; Zhang, B.S.; Steinhardt, R.C.; Mills, J.H.; Prescher, J.A. J. Am. Chem. Soc. 2020, 142, 14080.

(4) Coutant, E.P.; Goyard, S.; Hervin, V.O.; Gagnot, G.; Baatallah, R.; Rose, T.; Jacob, Y.; Janin, Y.L. Org. Biomol. Chem. 2019, 17, 3709; (b) Coutant, E.P.; Gagnot, G.; Hervin, V.O.; Baatallah, R.; Goyard, S.; Jacob, Y.; Rose, T.; Janin, Y.L. Chem. Eur. J. 2020, 26, 948.

(5) Abasolo, M.I.; Bianchi, D.; Atlasovitch, F.; Gaozza, C.; Fernandez, B.M. J. Heterocyclic Chem. 1990, 27, 157; (b) Bekerman, D.G.; Abasolo, M.I.; Fernandez, B.M. J. Heterocyclic Chem. 1992, 29, 129. 
(6) Janin, Y.L.; Huel, C.; Flad, G.; Thirot, S. Eur. J. Org. Chem. 2002, 1763.

(7) Rombouts, F.J.R.; Tresadern, G.; Buijnsters, P.; Langlois, X.; Tovar, F.; Steinbrecher, T.B.; Vanhoof, G.; Somers, M.; Andrés, J.-I.; Trabanco, A.A. ACS Med. Chem. Lett. 2015, 6, 282.

(8) Kato, T.; Sakamoto, T.; Kubo, A.; Sawamoto, D. Patent EP2896613

(9) Tanimori, S.; Kashiwagi, H.; Nishimura, T.; Kirihata, M. Adv. Synth. Catal. 2010, 352, 2531.

(10) Scarry, S.M.; Lovell, K.M.; Frankowski, K.J.; Bohn, L.M.; Aubé, J. J. Org. Chem. 2016, 81, 10538.

(11) (a) An, Z.; She, Y.; Yang, X.; Pang, X.; Yan, R. Org. Chem. Front. 2016, 3, 1746; (b) Rajasekar, S. ; Adarsh, T. P.; Tharmalingam, N. ; Andivelu, I. ; Mylonakis, E. Chemistry Select 2019, 4, 2281; (c) Chu, L.; Yue, X.; Qing, F.L. Org. Lett. 2010, 12, 1644; (d) Deguchi, Y.; Kono, M.; Koizumi, Y.; Izato, Y.; Miyake, A. Org. Process Res. Dev. 2020, 24, 1614.

(12) Han, C.; Kelly, S.M.; Cravillion, T.; Savage, S.J.; Nguyen, T.; Gosselin, F. Tetrahedron 2019, 75, 4351.

(13) (a) Mamedov, V.A. RSC Adv. 2016, 6, 42132; (b) Mamedov, V.A.; Zhukova, N.A.; Kadyrova, M.S.; Syakaev, V.V.; Beschastnova, T.N.; Buzyurova, D.N.; Rizvanov, I.K.; Latypov, S.K.; Sinyashin, O.G. J. Org. Chem. 2019, 84, 13572.

(14) Vacher, M.; Fdez Galván, I.; Ding, B.W.; Schramm, S.; Berraud-Pache, R.; Naumov, P.; Ferré, N.; Liu, Y.J.; Navizet, I.; Roca-Sanjuán, D.; Baader, W.J.; Lindh, R. Chem. Rev. 2018, 118, 6927.

(15) Wang, S.L.; Ding, J.; Jiang, B.; Gao, Y.; Tu, S.J. ACS Comb. Sci. 2011, 13, 572. 


\section{Supplementary material}

Crystallization, data collection, and structure determination

Chemiluminescence spectra

${ }^{1} \mathrm{H}$ and ${ }^{13} \mathrm{C}$ spectra of the compounds described

Crystallization, data collection, and structure determination

Suitable crystals of compounds $\mathbf{1 7}$ and $\mathbf{2 2}$ were obtained by recrystallization in ethanol. Crystals were then flash-cooled in liquid nitrogen using Paratone-paraffin 50\% (v/v) oil as the cryoprotectant. X-ray diffraction data were collected at a wavelength of $0.7293 \AA$ on the beamline PROXIMA-2 at Synchrotron SOLEIL (St. Aubin, France). Diffraction data were integrated and reduced using the XDS program package. ${ }^{1}$ Structures were solved using SHELXT ${ }^{2}$ and refined with SHELXL. ${ }^{3}$

Parameters for compound 17: Data Block Name: data_c17ca_a, Unit Cell Parameters: a 20.870(4) b 20.870(4) c 13.650(3) R-3, CCDC Deposition Number: 2056217 (see https://www.ccdc.cam.ac.uk/structures/), DOI: 10.5517/ccdc.csd.cc270nlj, CSD Entry: AKASAJ.

Parameters for compound 22: Data Block Name: data_c22ca, Unit Cell Parameters: a 32.03760(10) b 9.447(2) c 7.562(2) Pcca, CCDC Deposition Number: 2056386 (see https://www.ccdc.cam.ac.uk/structures/), DOI: $10.5517 /$ ccdc.csd.cc270v15, CSD Entry: EKASIV.

1. Kabsch, W. Acta Cryst. 2010, D66, 125.

2. Sheldrick, G.M. Acta Cryst. A 2015, A71, 3.

3. Sheldrick, G.M. Acta Cryst. 2015, C71, 3. 


\section{Chemiluminescence spectra}

The time-dependent chemiluminescence signal was recorded using an Aqualog (HORIBA Instruments, Inc.) equipped with thermoelectrically cooled charge-coupled device (CCD) array detector. The system uses a xenon-arc light source to excite samples and two detectors for simultaneous Absorbance, Transmission and emission analysis was adapted to the chemiluminescence analysis by blocking the excitation source. The 2D emission spectra were recorded from 250 to $800 \mathrm{~nm}$ using $5 \mathrm{~nm}$ step, high gain and $30 \mathrm{~s}$ integration time for emission detection. A detector accumulation of 2 has been chosen to improve the Signal-to-noise Ratio and increase the photons counts.

Chemiluminescence data were corrected for the instrumental emission spectral response, detector dark currents and blank sample emission. All samples were analyzed using $1 \mathrm{~cm}$ path length fluorescence quartz cuvettes and the signal was recorded immediately after addition of, respectively, 1 or $2 \mu \mathrm{L}$ of a $5 \mathrm{mM}$ stock solution of the O-acteylated luciferins $\mathbf{2 7}$ or $\mathbf{3 5}$ on $2 \mathrm{~mL}$ of a phosphate buffer DPBS GIBCO $1 \mathrm{X}$ which also contained $2.5 \mathrm{mM}$ of CTAB. The chemiluminescence data were analyzed using Aqualog software based on OriginLab® and as depicted below, the signal was smoothed by 4 points fast Fourier transform (FFT).

Spectra of compound 27

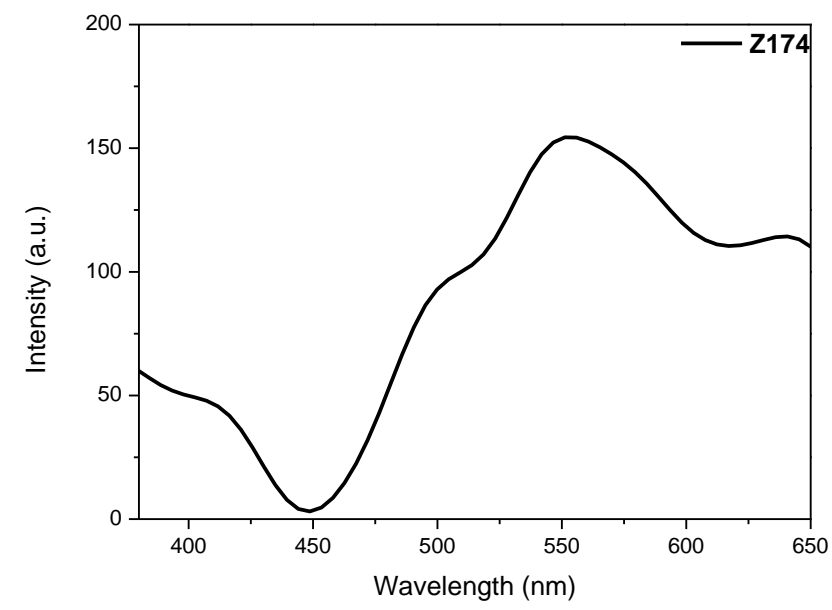

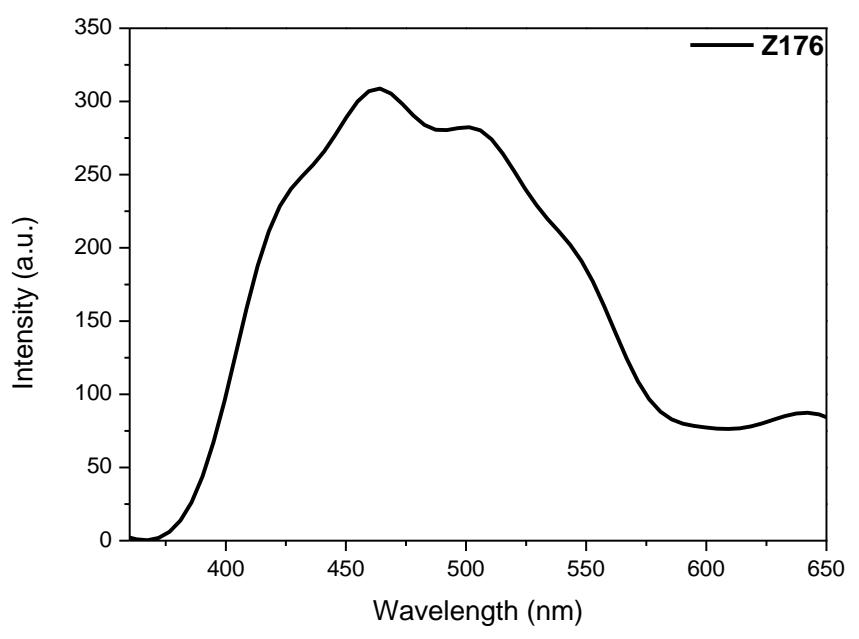

Spectra of compound $\mathbf{3 5}$ 

${ }^{1} \mathrm{H}$ and ${ }^{13} \mathrm{C}$ spectra of the compounds described

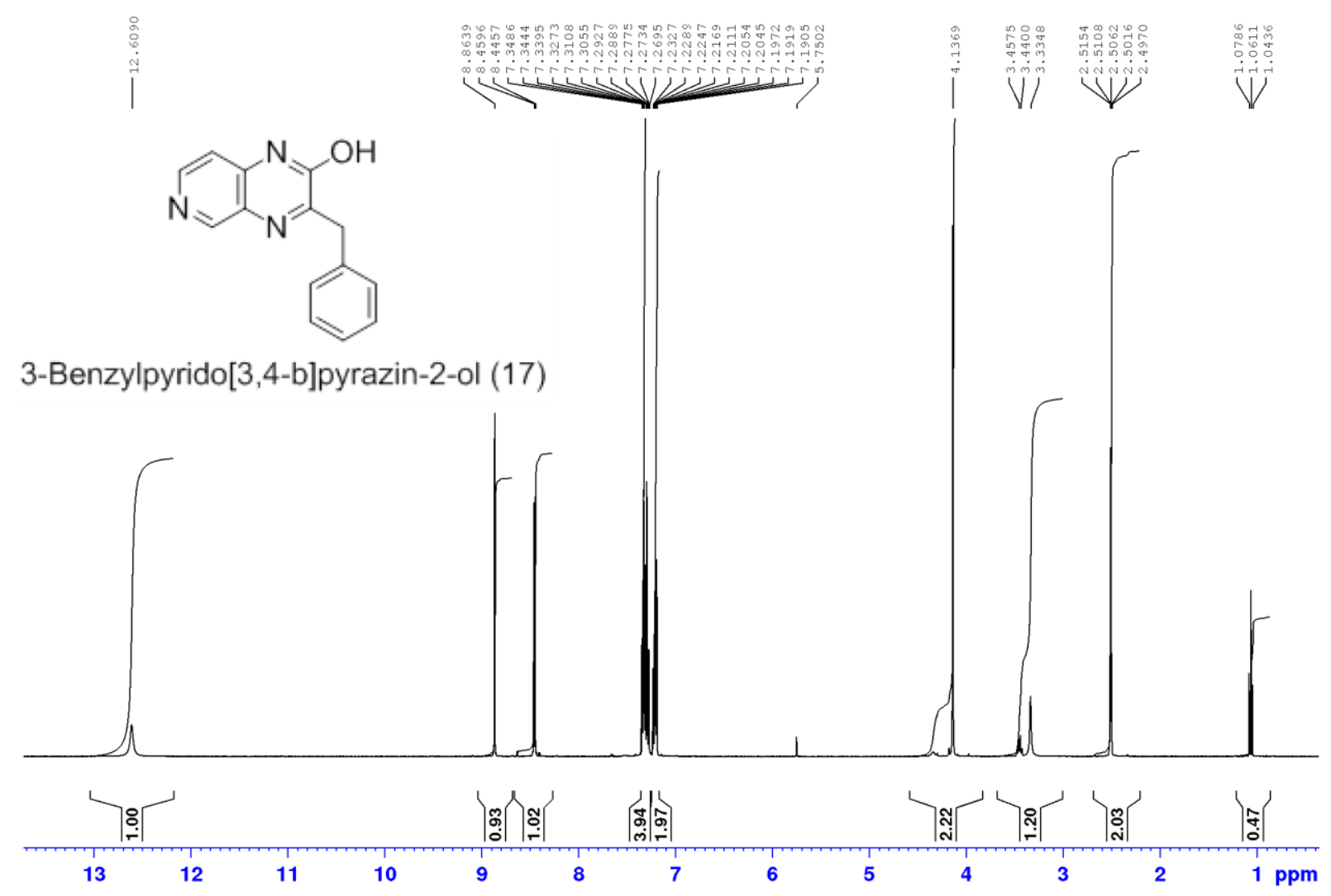



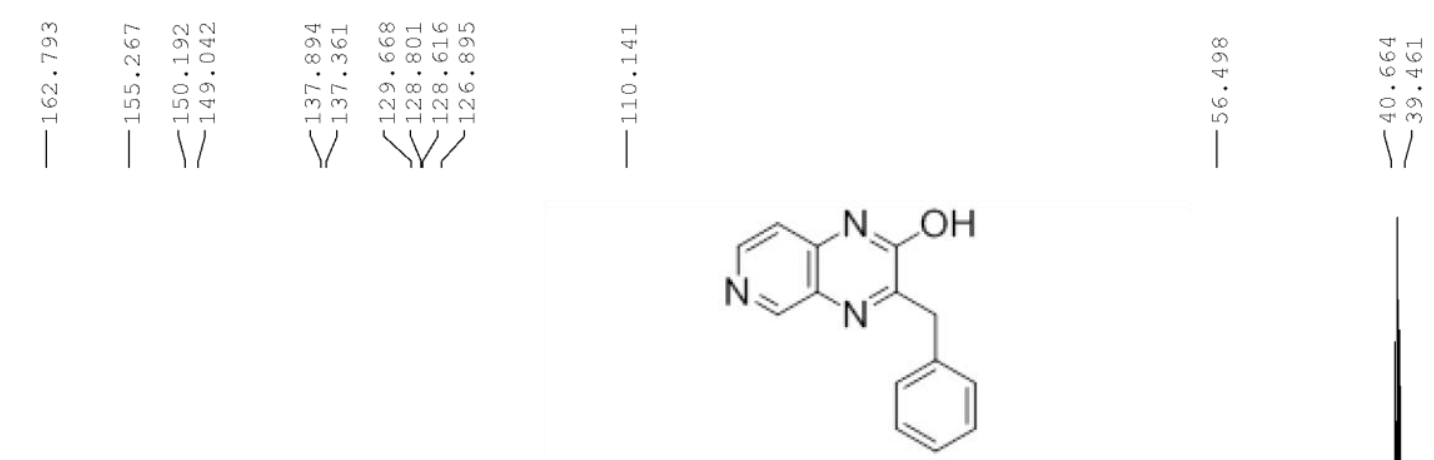

3-Benzylpyrido[3,4-b]pyrazin-2-ol (17)
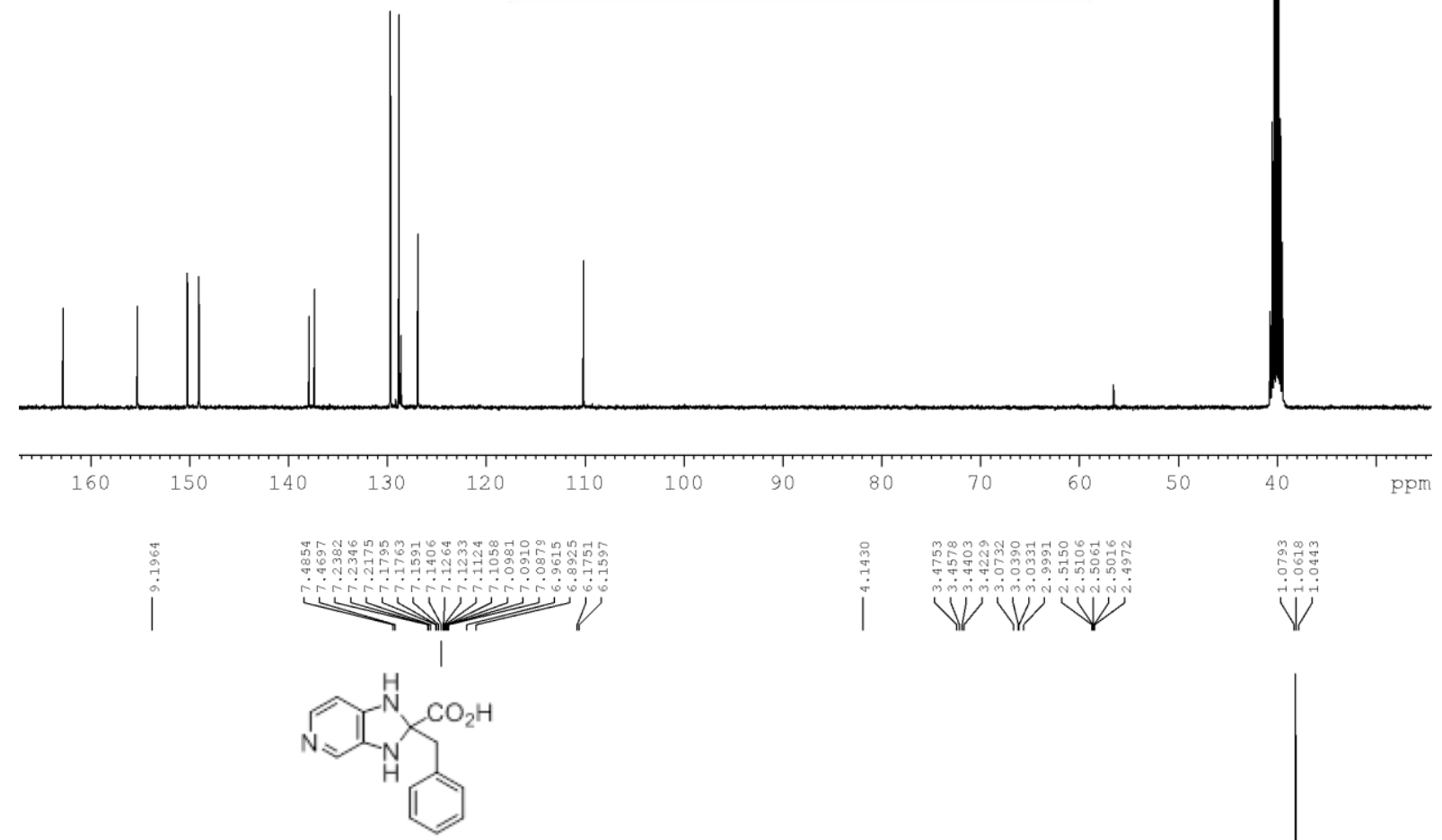

2-Benzyl-2,3-dihydro-1H-imidazo[4,5-c]pyridine-2-carboxylic acid (18)

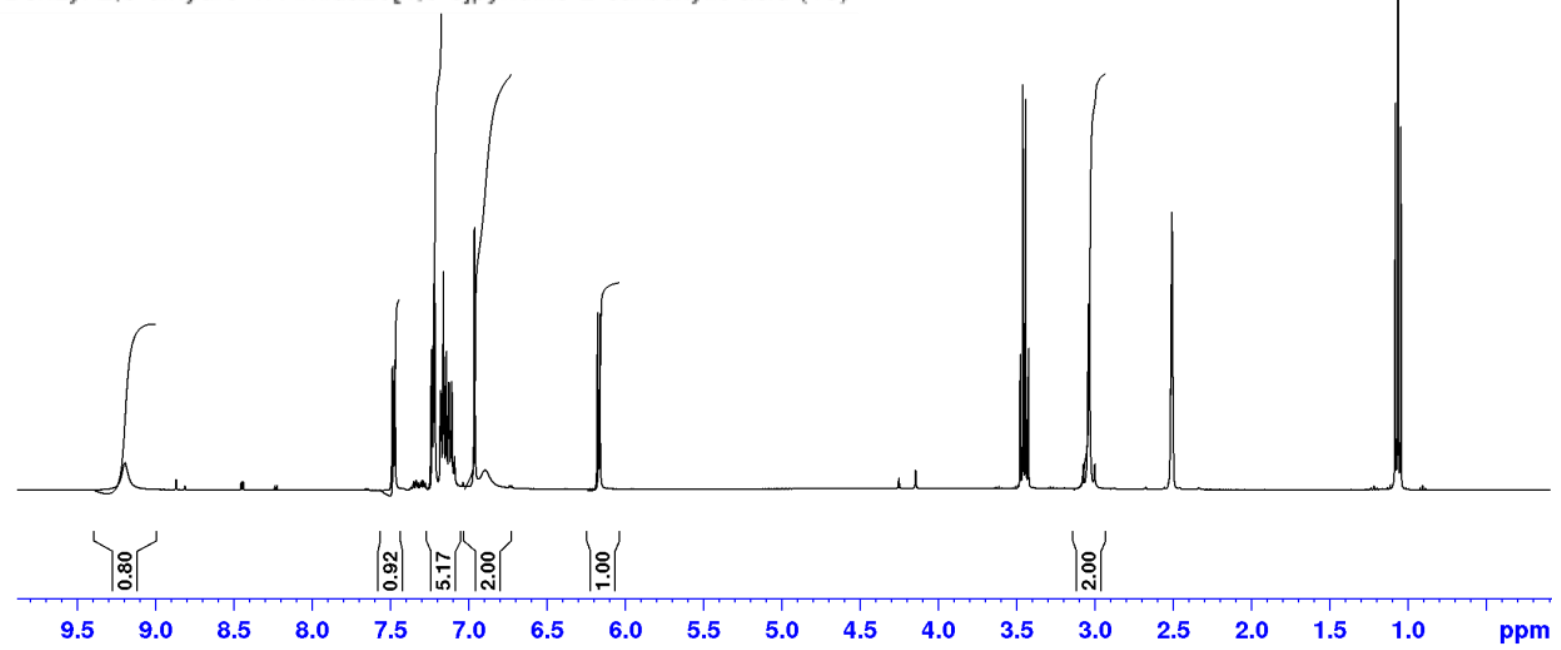



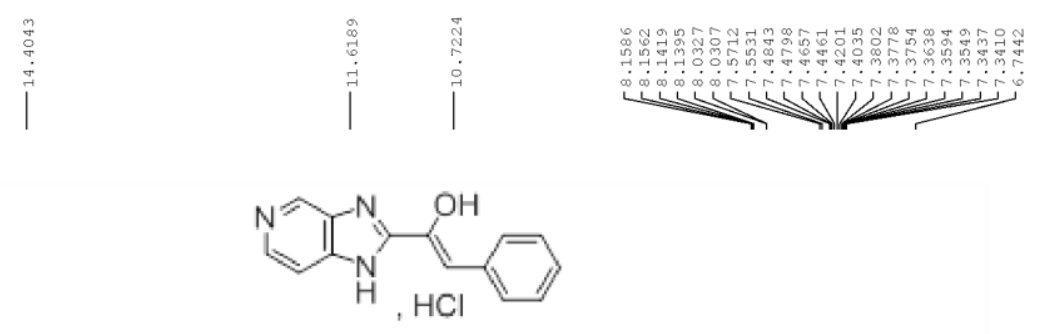

1-(1H-imidazo[4,5-c]pyridin-2-yl)-2-phenylethen-1-ol hydrochloride salt (19)
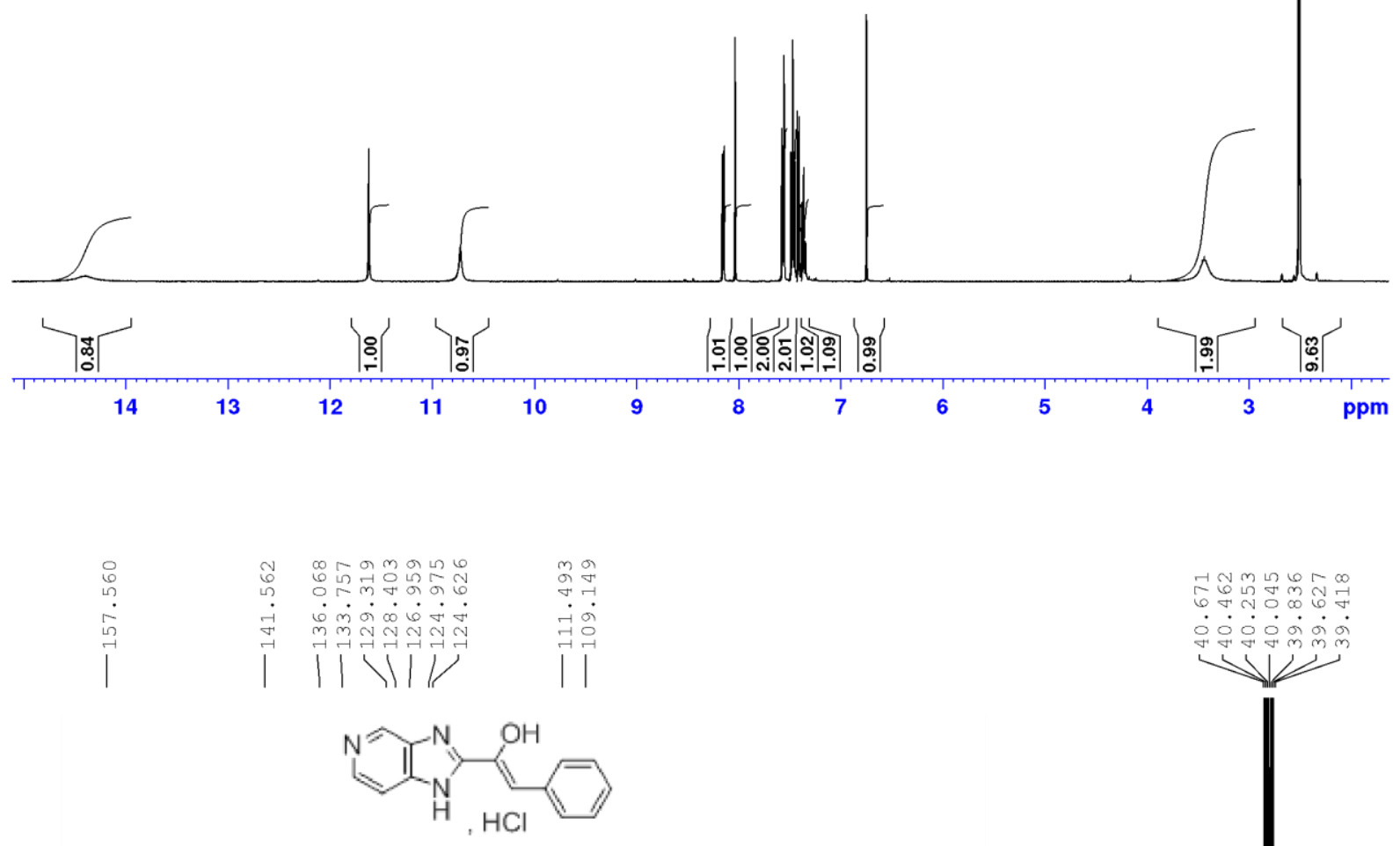

1-(1H-imidazo[4,5-c]pyridin-2-yl)-2-phenylethen-1-ol hydrochloride salt (19)

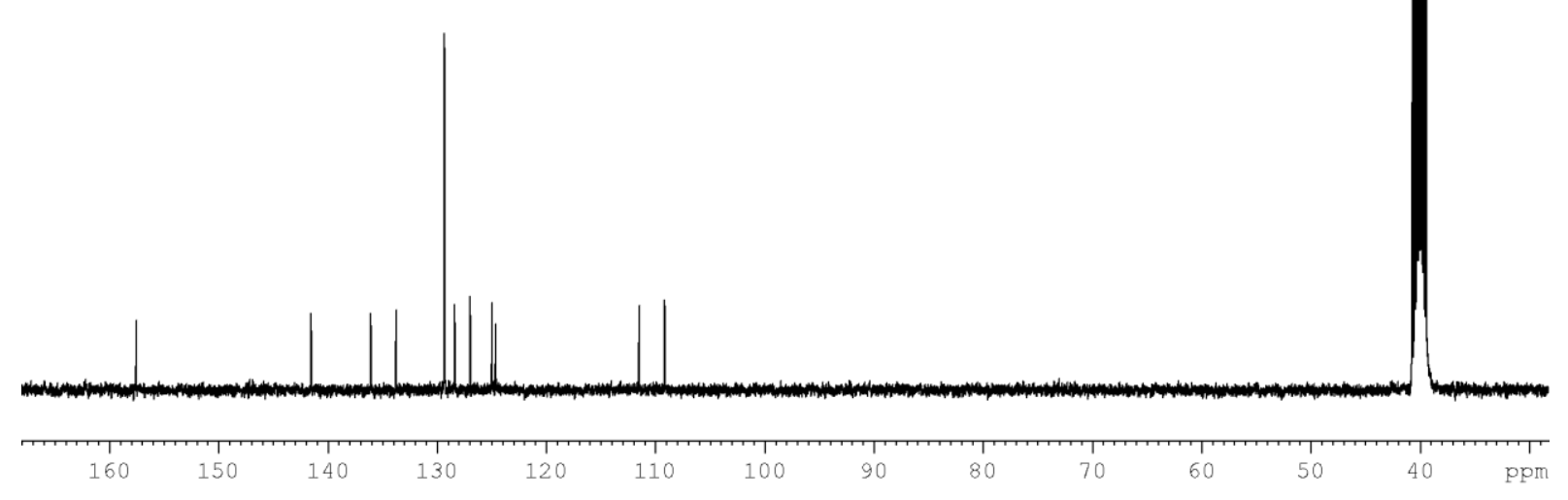



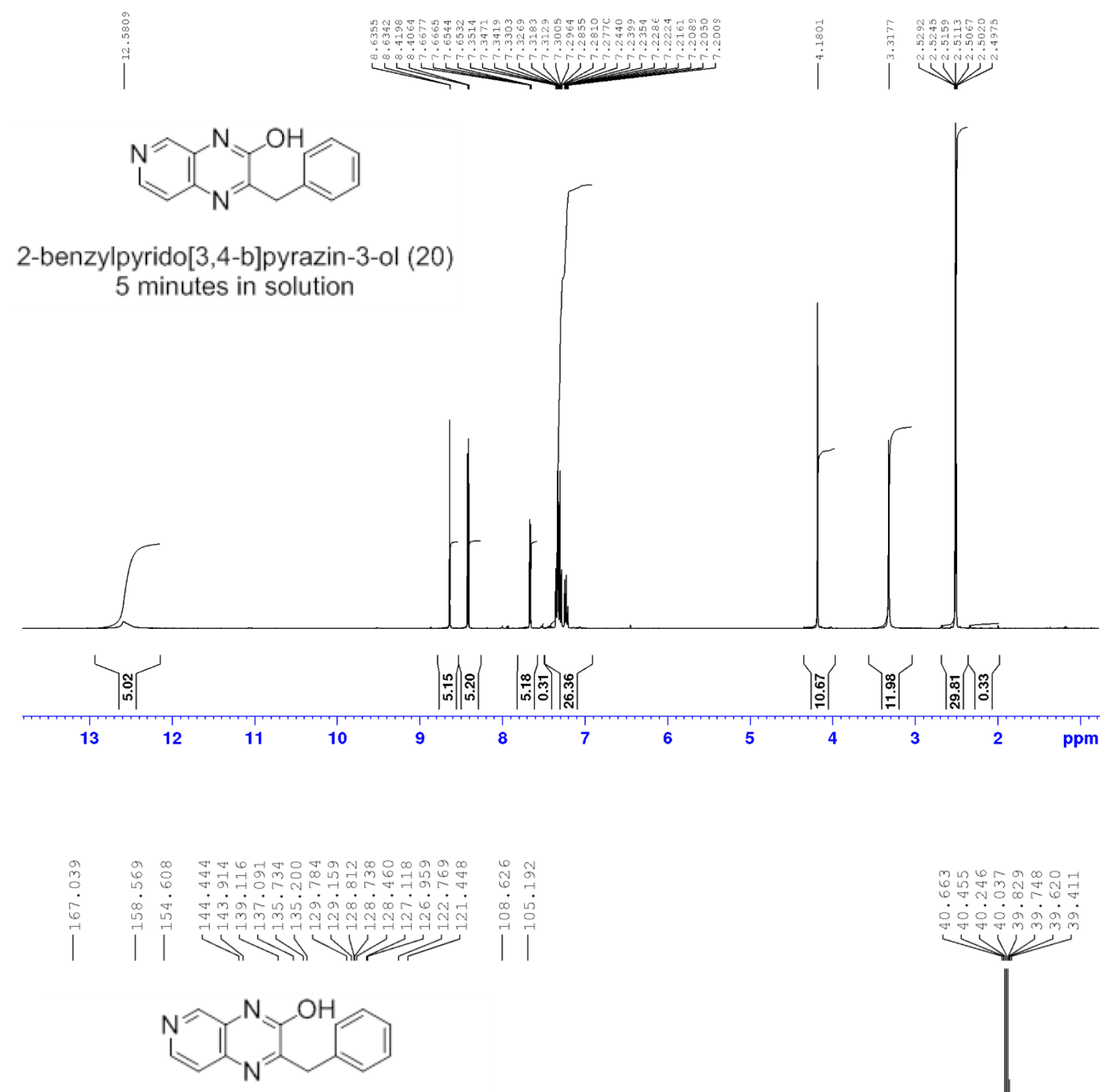

2-benzylpyrido[3,4-b]pyrazin-3-ol (20) 25 minutes in solution

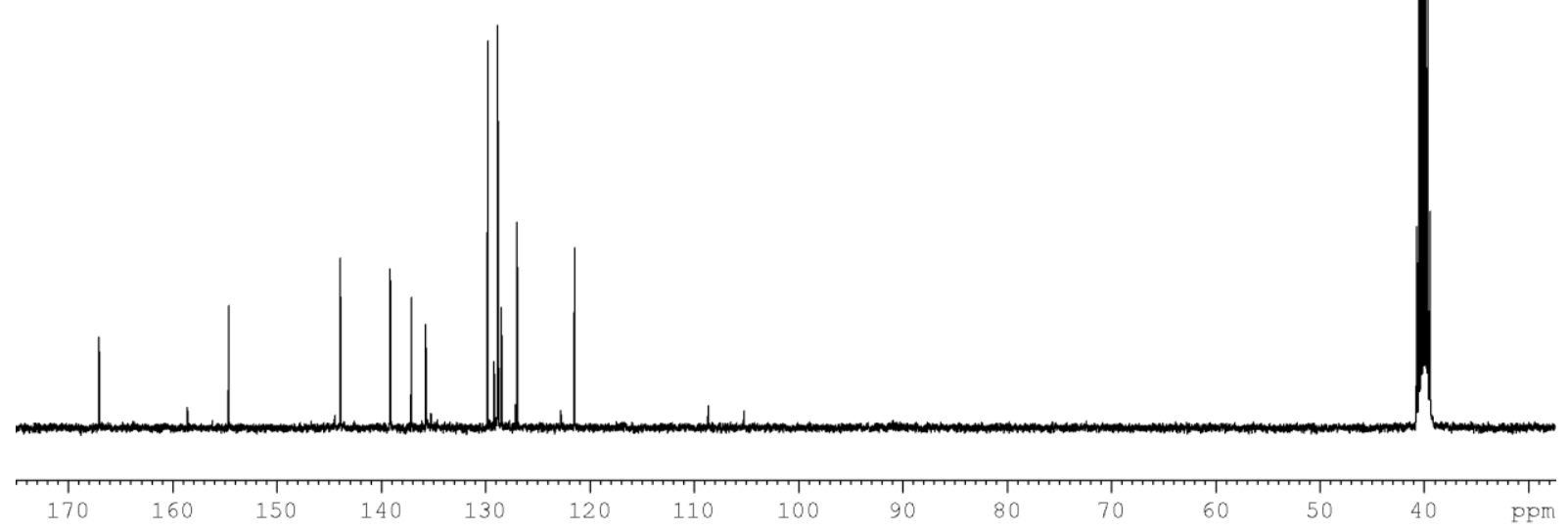




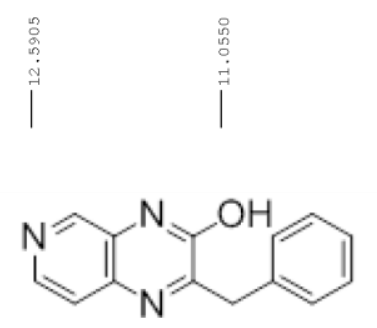

2-benzylpyrido[3,4-b]pyrazin-3-ol (20) 1 hour in solution
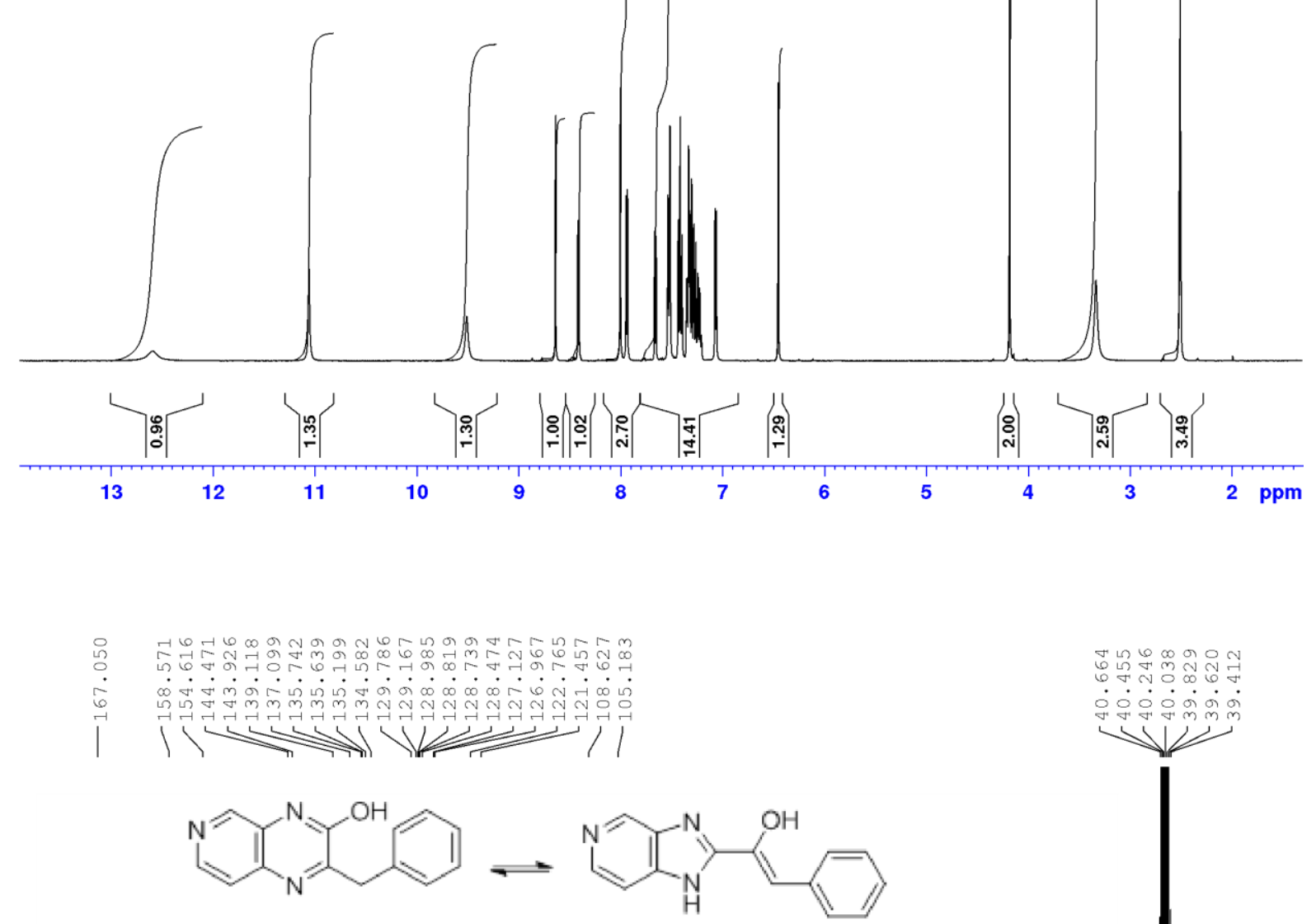
2-benzylpyrido[3,4-b]pyrazin-3-ol (20) 1-(1H-imidazo[4,5-c]pyridin-2-yl)-2-phenylethen-1-ol
1 hour in solution

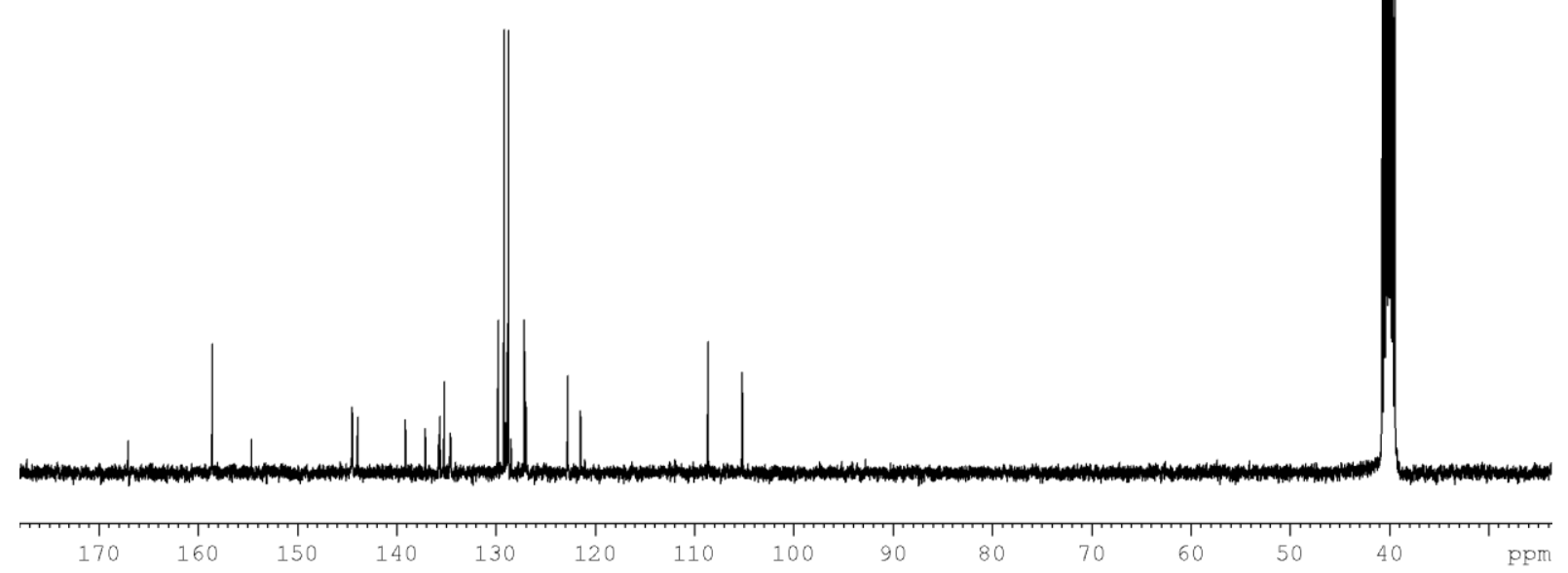



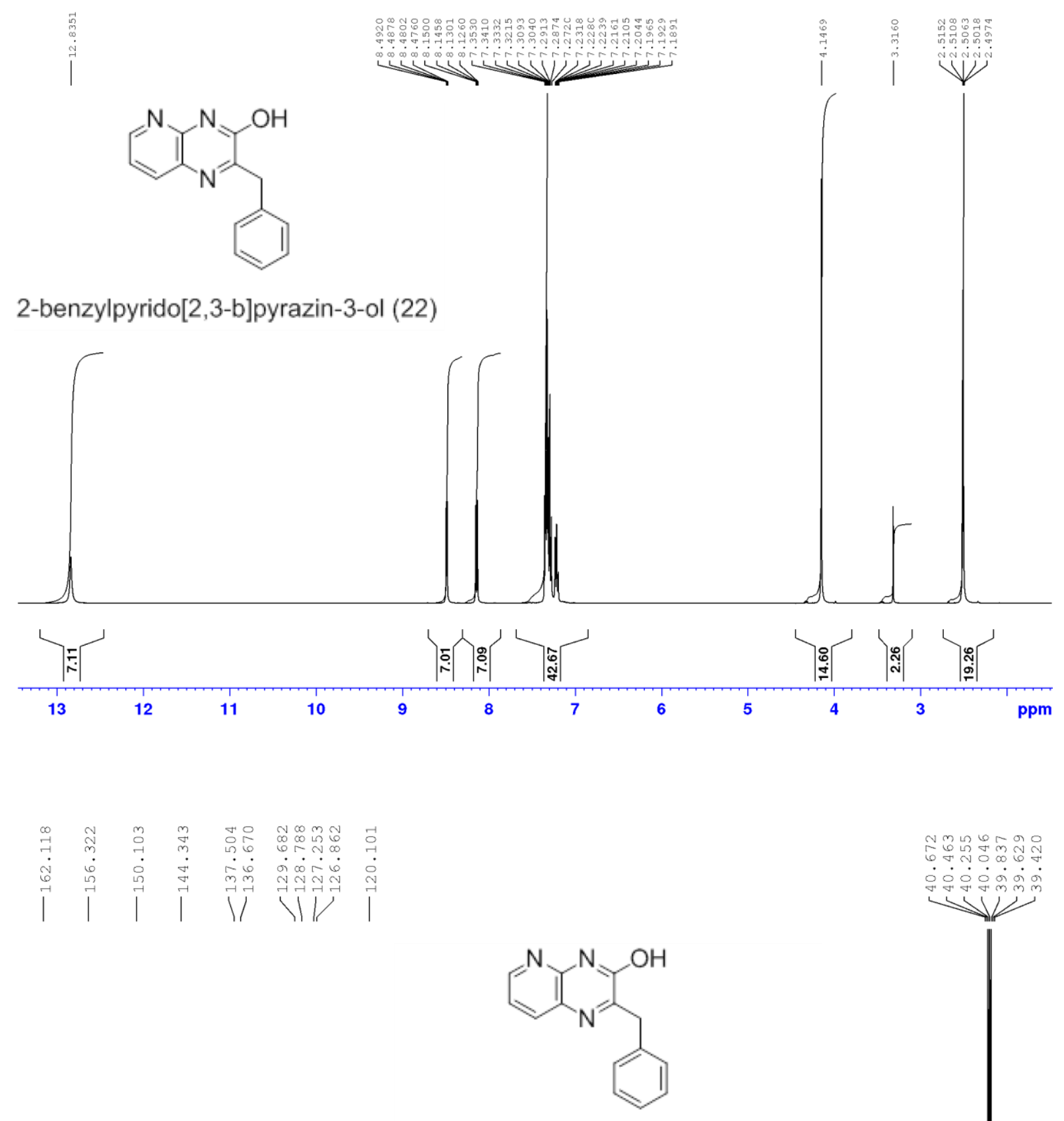

2-benzylpyrido[2,3-b]pyrazin-3-ol (22)

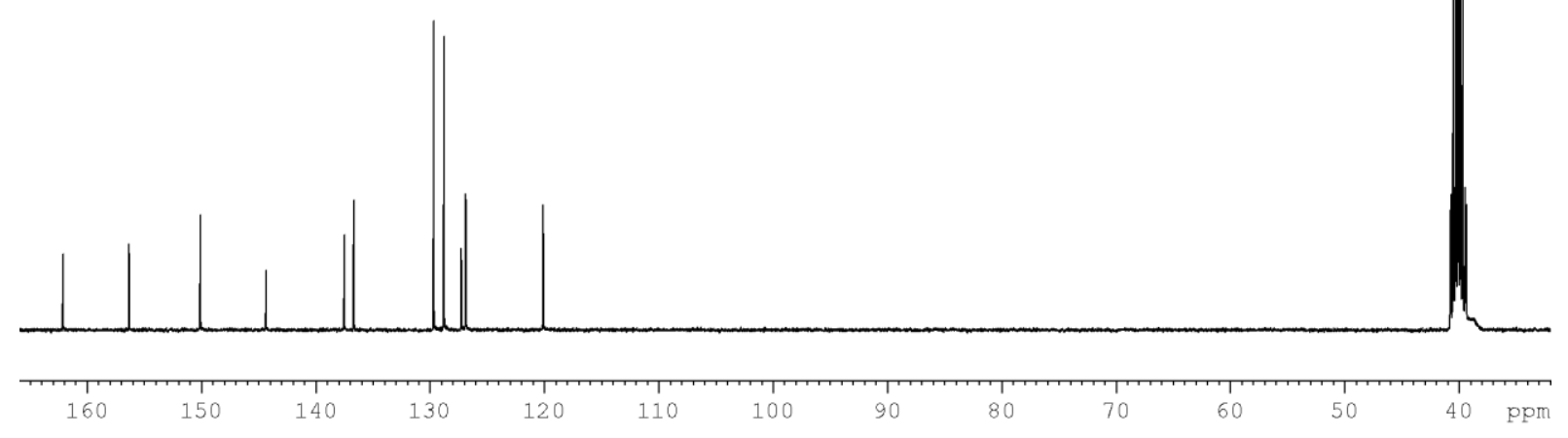



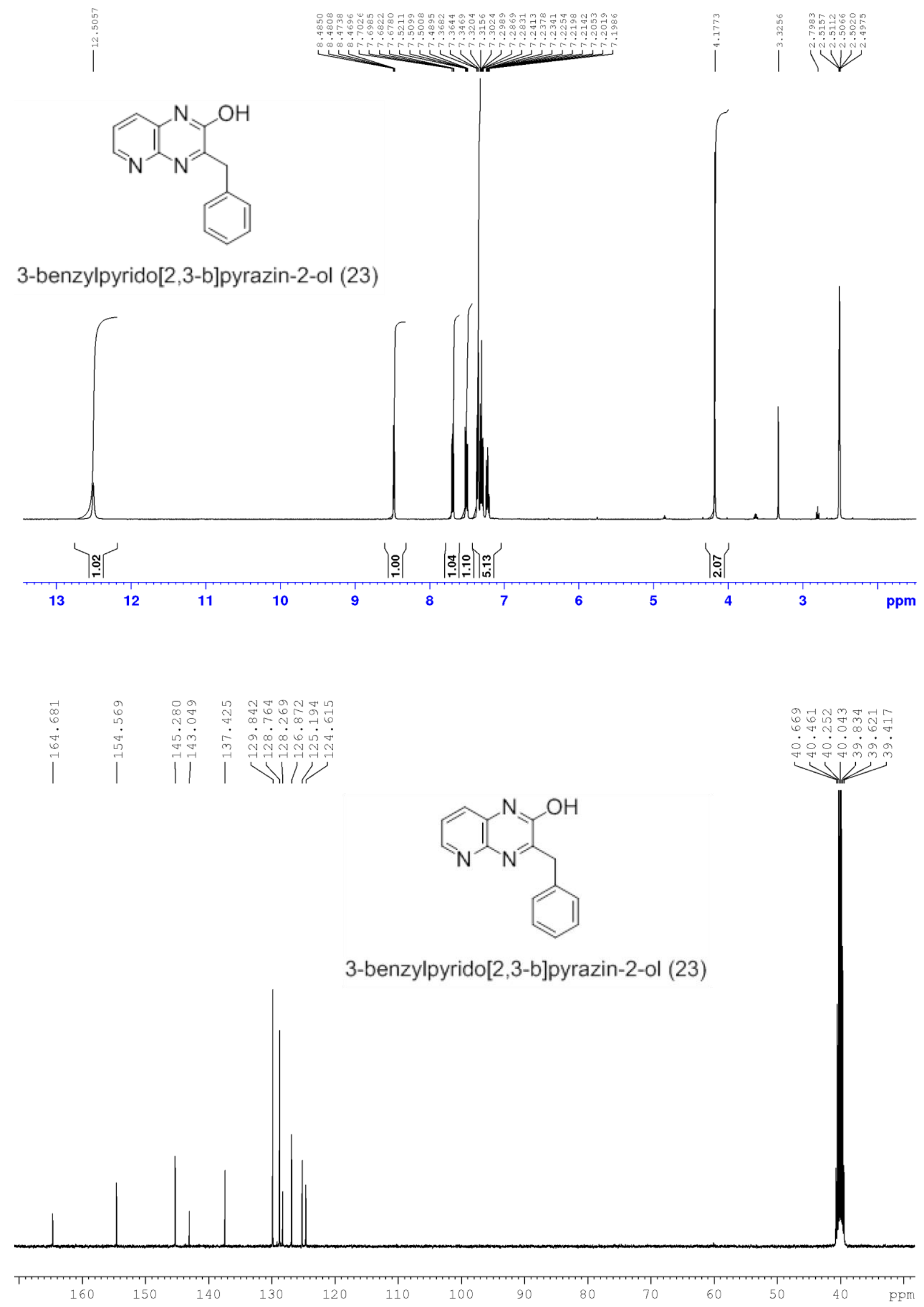

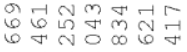

பं்சंன்

W 


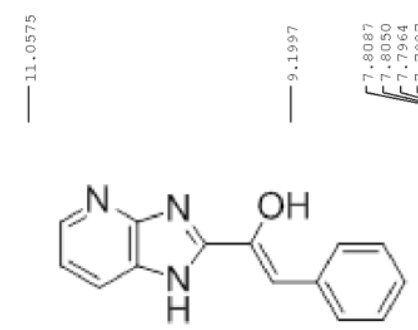

1-(1H-Imidazo[4,5-b]pyridin-2-yl)-2-phenylethen-1-ol (24)
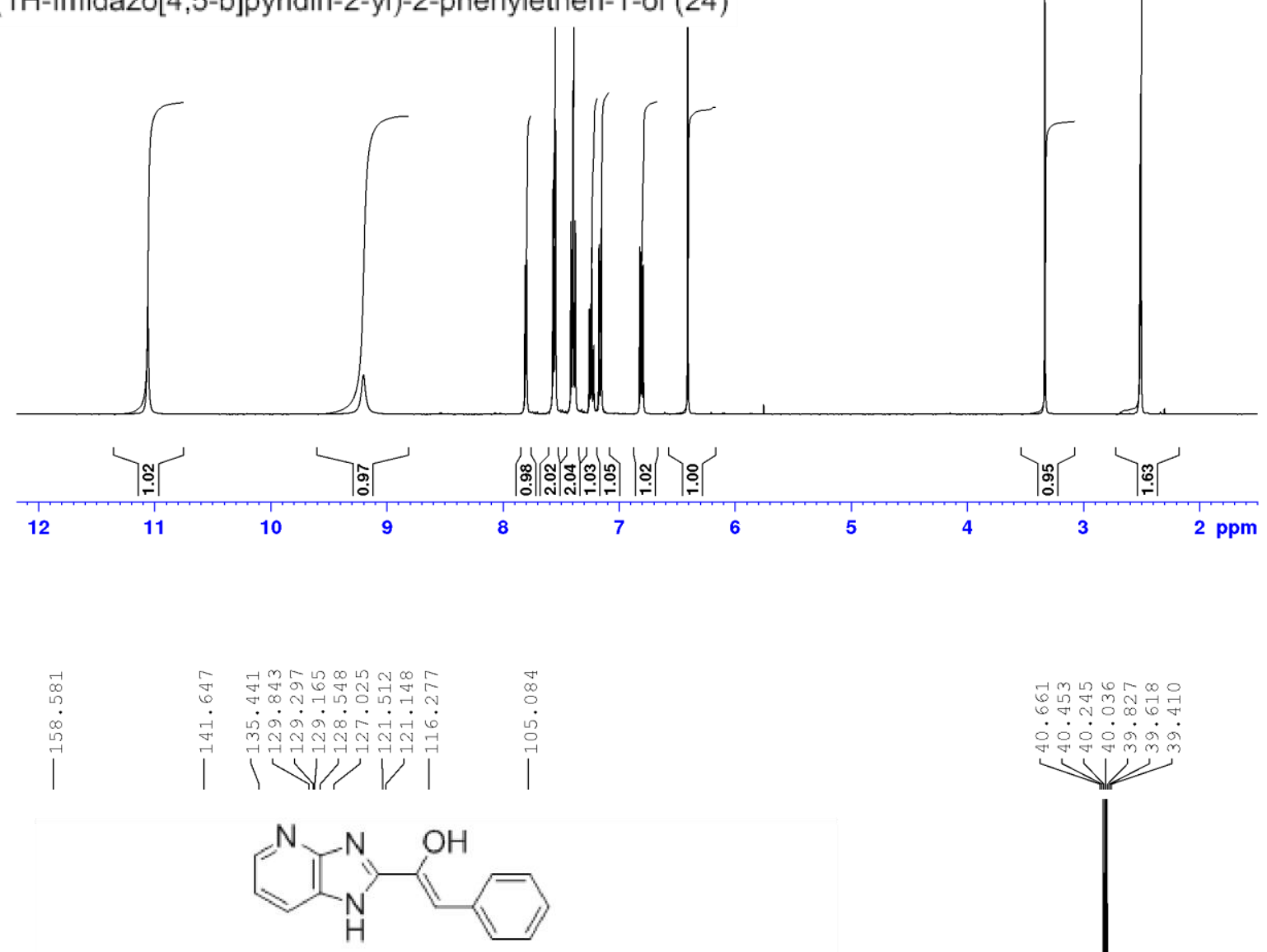

1-(1H-Imidazo[4,5-b]pyridin-2-yl)-2-phenylethen-1-ol (24)
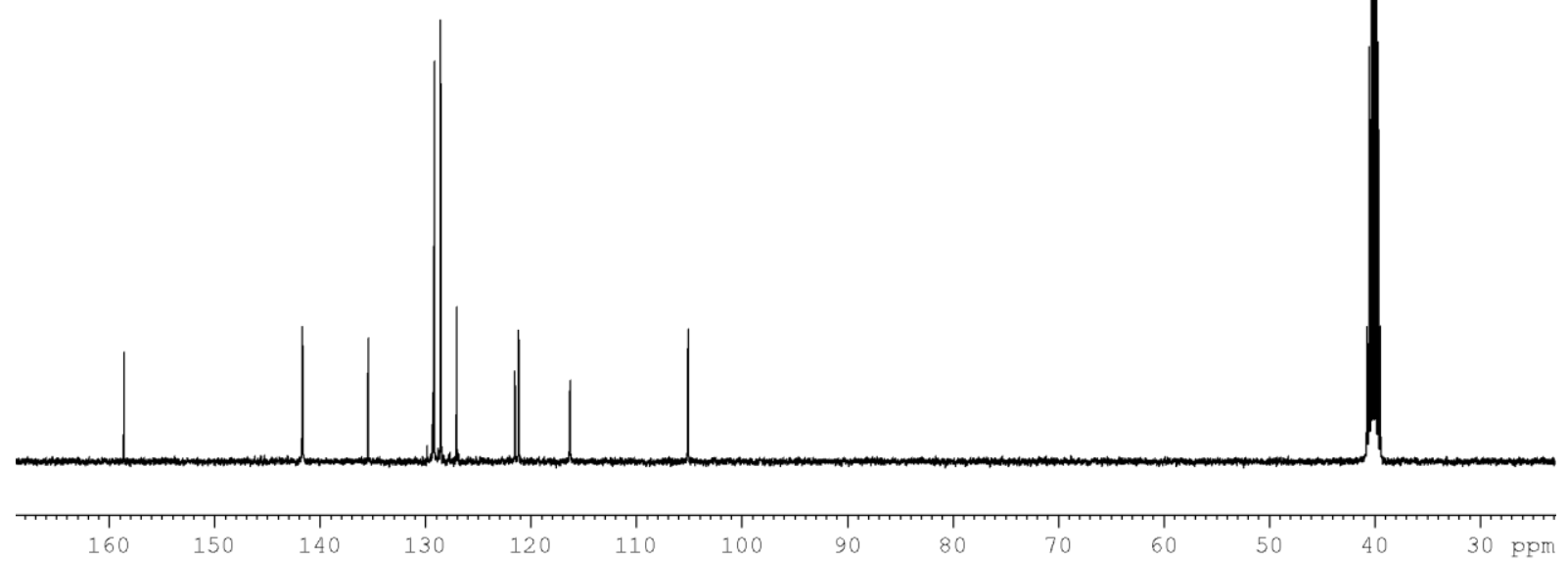


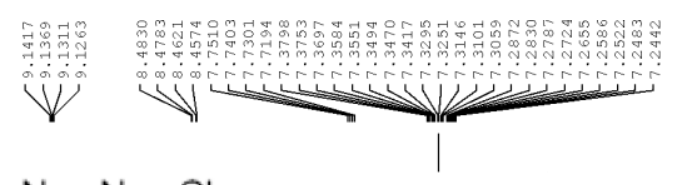

|<smiles>Clc1nc2ncccc2nc1Cc1ccccc1</smiles>

2-Benzyl-3-chloropyrido[2,3-b]pyrazine (13)

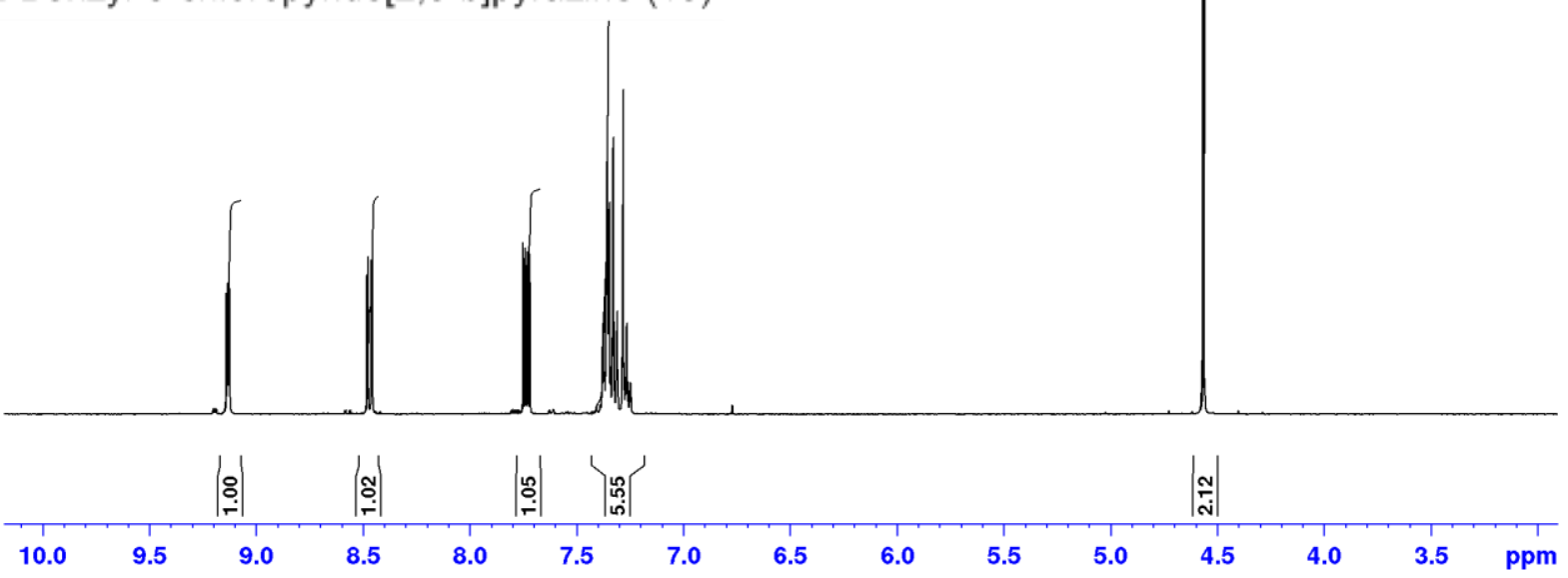

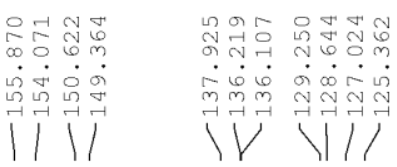<smiles>Clc1nc2ncccc2nc1Cc1ccccc1</smiles>

2-Benzyl-3-chloropyrido[2,3-b]pyrazine (13)

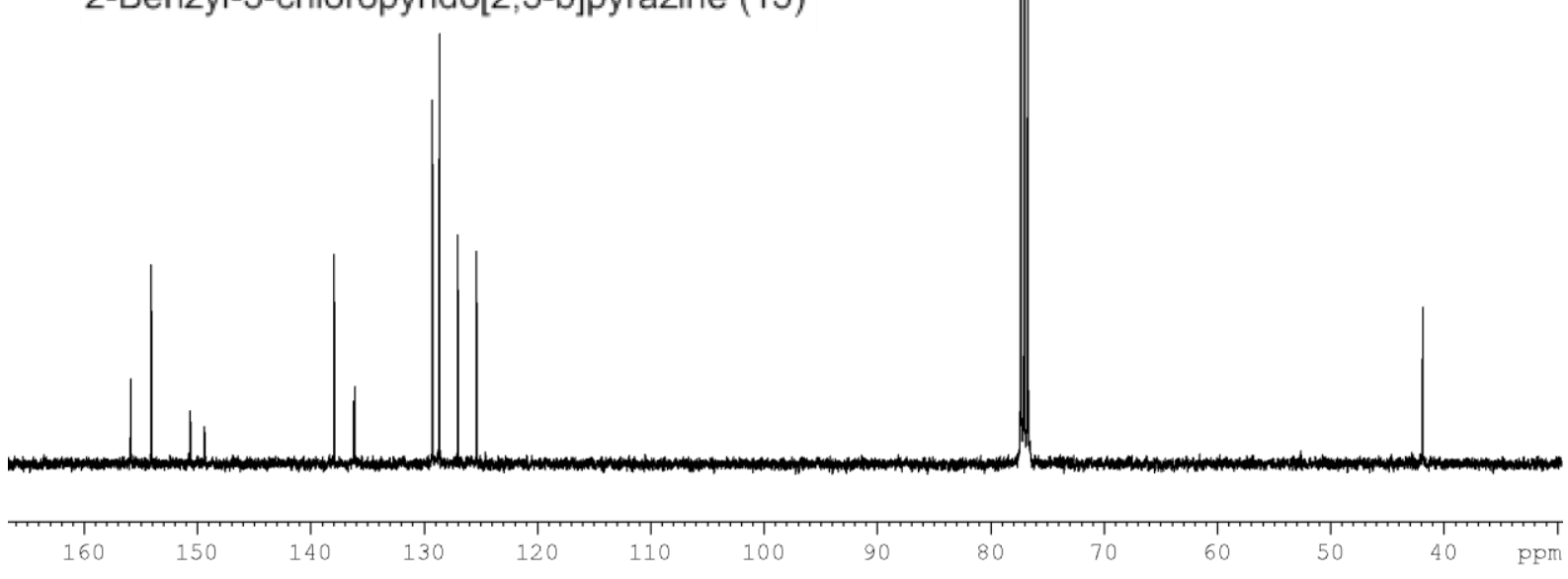



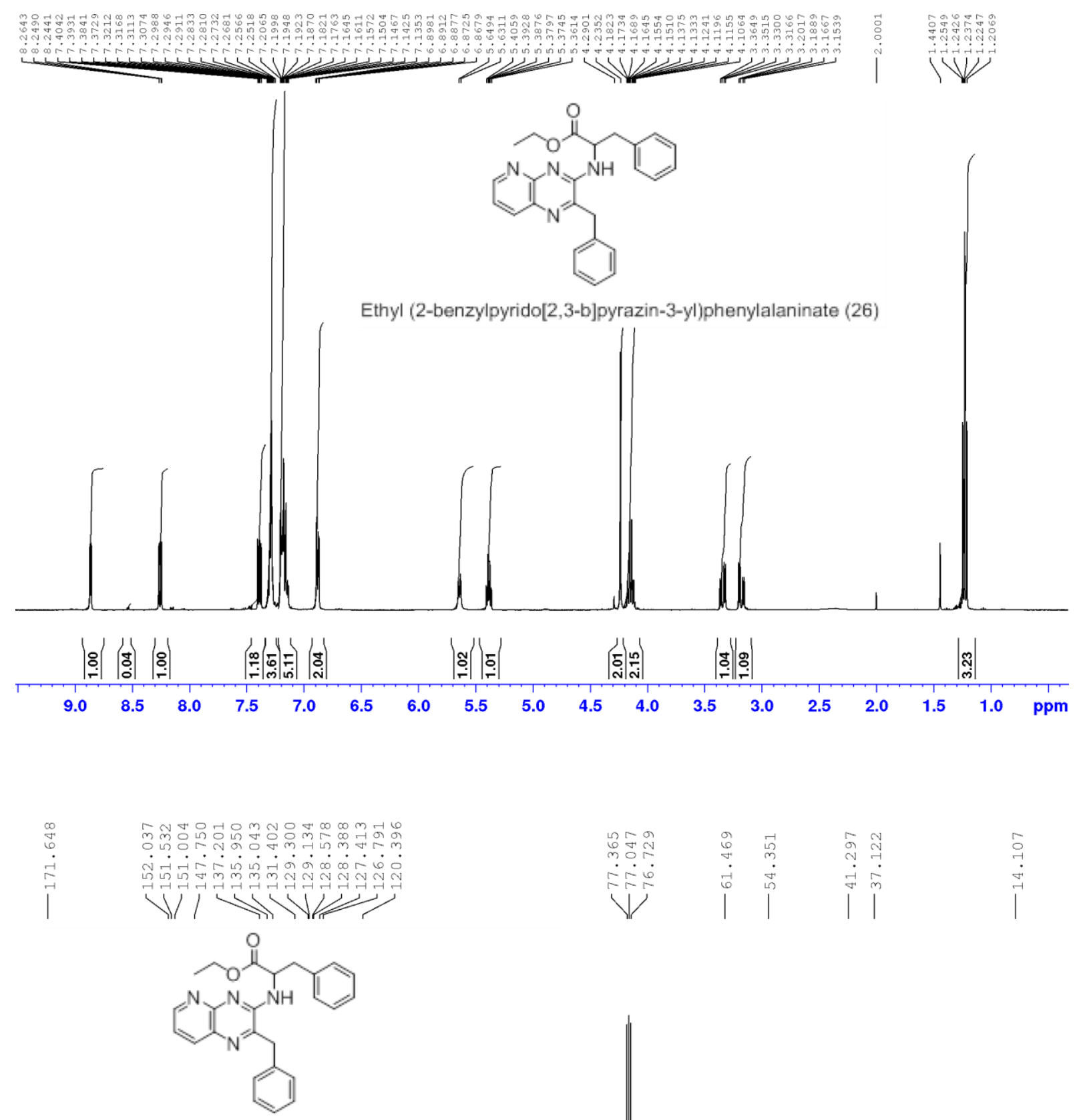

Ethyl (2-benzylpyrido[2,3-b]pyrazin-3-yl)phenylalaninate (26)
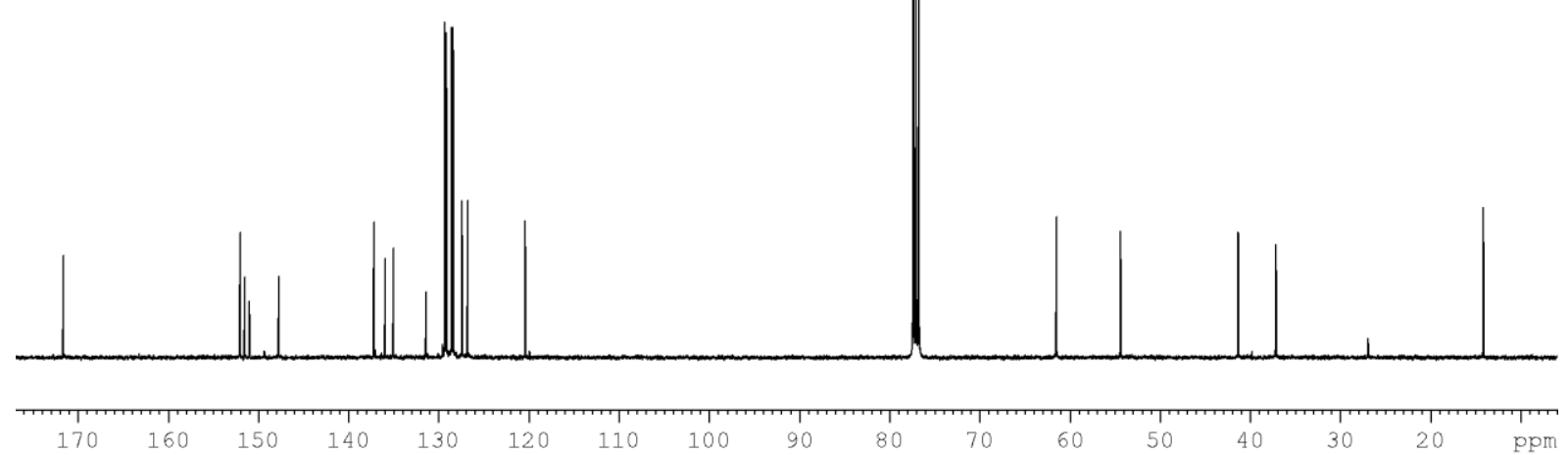

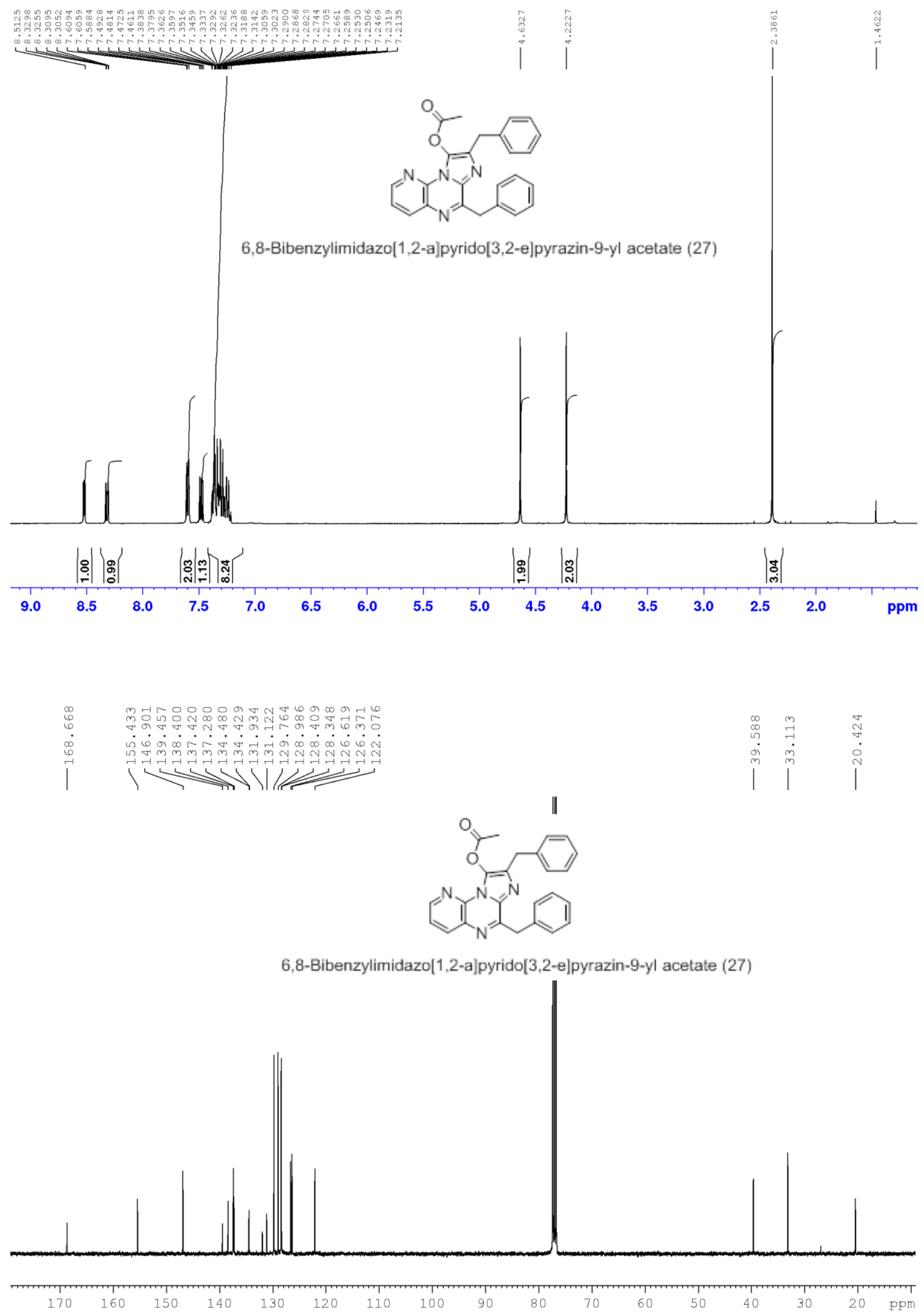


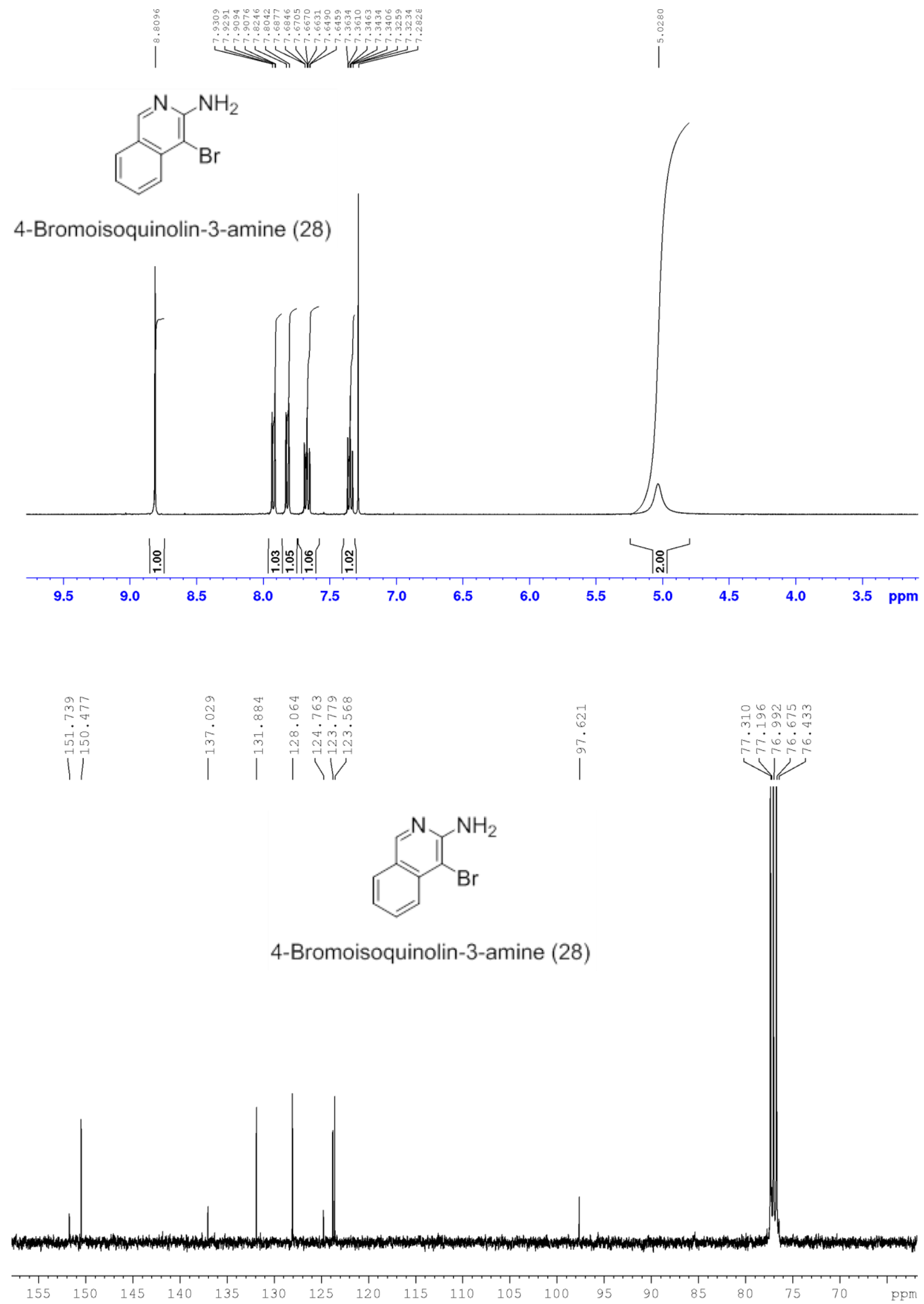


Note: add one to the compound number depicted<smiles></smiles>

2-Benzylpyrazino[2,3-c]isoquinolin-3-ol (31)
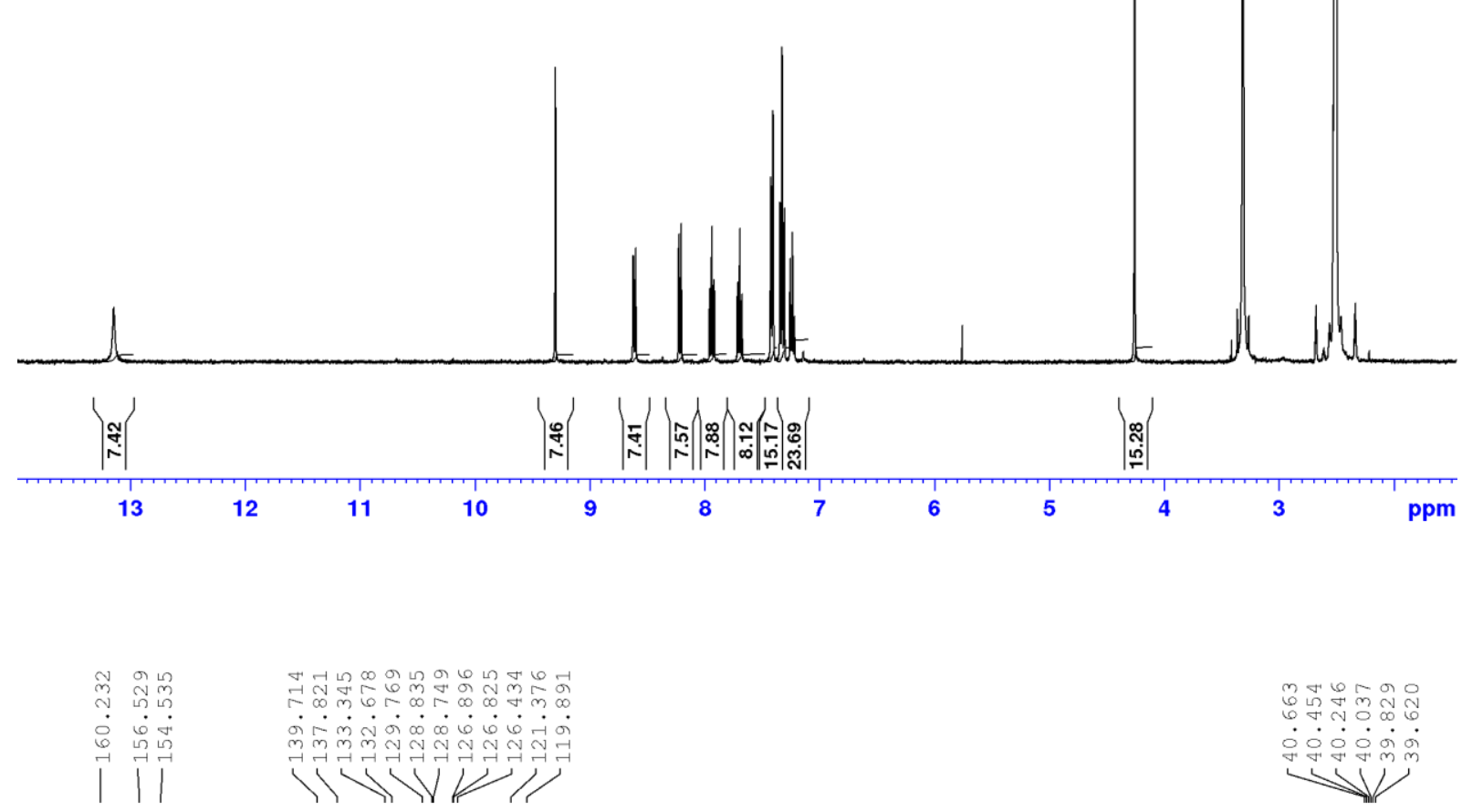<smiles>Oc1nc(Cc2ccccc2)c2ccccc2n1</smiles>

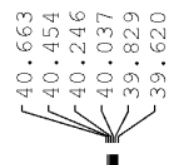

2-Benzylpyrazino[2,3-c]isoquinolin-3-ol (31)

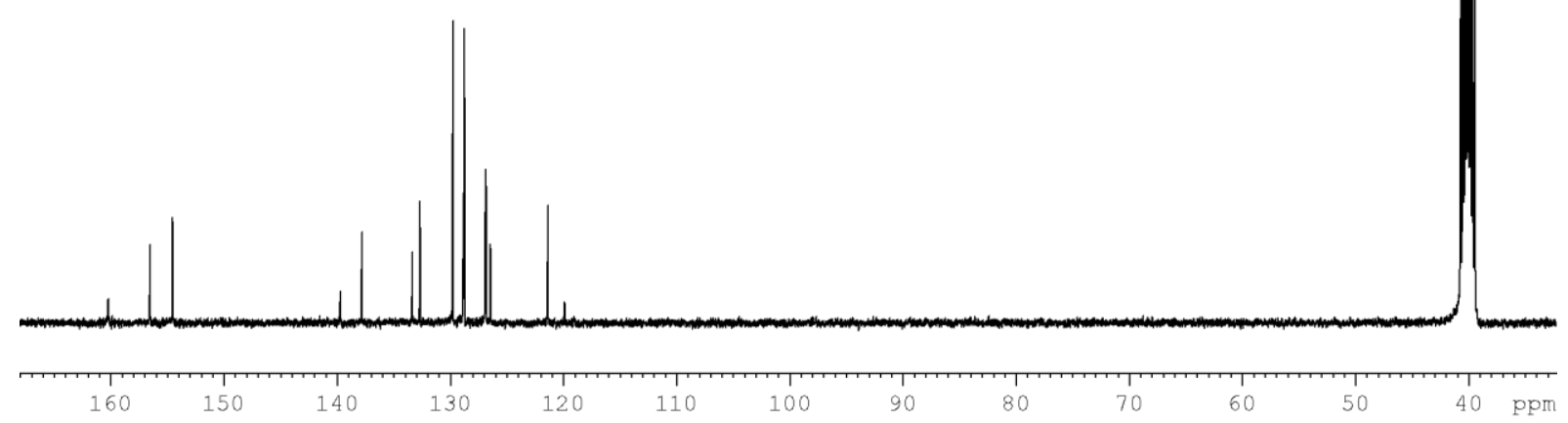


Note: add one to the compound number depicted
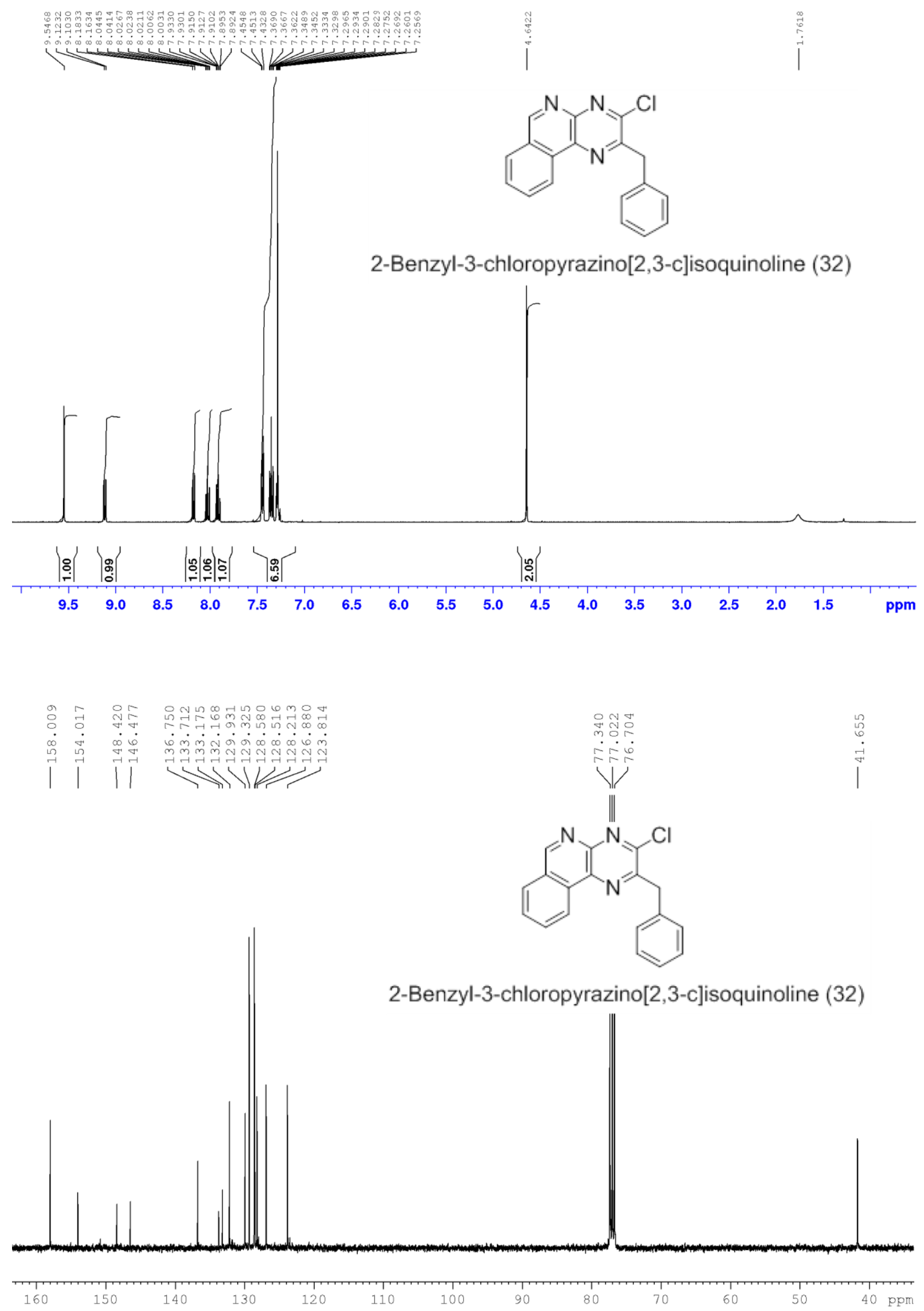
Note: add one to the compound number depicted
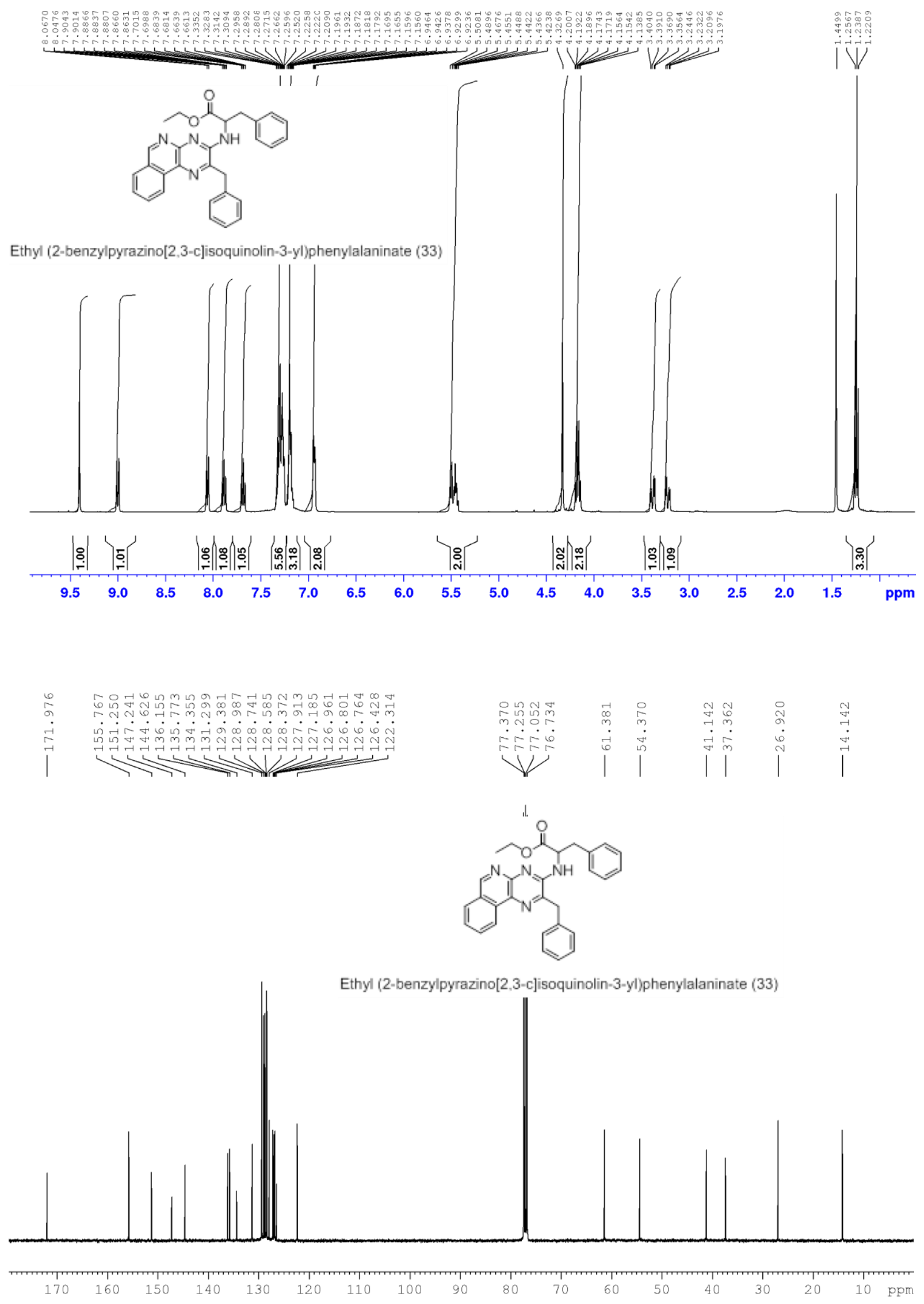
Note: add one to the compound number depicted

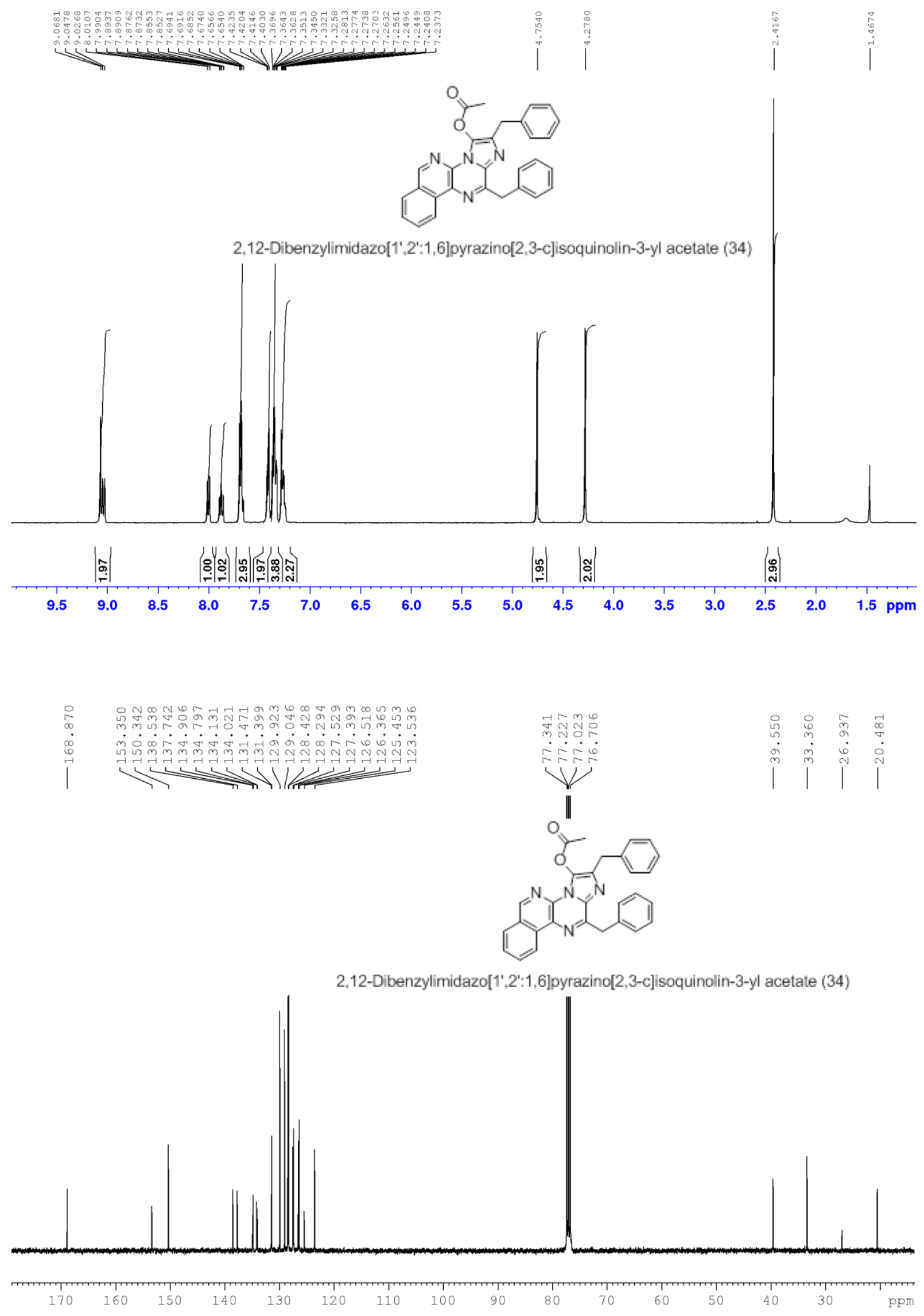


